\title{
Hard and Soft Anatomy in Two Genera of Dondersiidae (Mollusca, Aplacophora, Solenogastres)
}

\author{
AMÉLIE H. SCHELTEMA ${ }^{1, *}$, CHRISTOFFER SCHANDER ${ }^{2} \dagger$, AND KEVIN M. KOCOT ${ }^{3}$ \\ ${ }^{1}$ Woods Hole Oceanographic Institution, Biology Dept., Woods Hole, Massachusetts 02543; ${ }^{2}$ University \\ Museum of Bergen, P.O. Box 7800, Bergen N-5020, Norway; Uni Environment, Uni Research AS, \\ Bergen N-5020, Norway; and ${ }^{3}$ Department of Biological Sciences, Auburn University, \\ 101 Rouse Life Sciences, Auburn, Alabama 36849
}

\begin{abstract}
Phylogenetic relationships and identifications in the aplacophoran taxon Solenogastres (Neomeniomorpha) are in flux largely because descriptions of hard partssclerites, radulae, copulatory spicules-and body shape have often not been adequately illustrated or utilized. With easily recognizable and accessible hard parts, descriptions of Solenogastres are of greater use, not just to solenogaster taxonomists, but also to ecologists, paleontologists, and evolutionary biologists. Phylogenetic studies of Aplacophora, Mollusca, and the Lophotrochozoa as a whole, whether morphological or molecular, would be enhanced. As an example, morphologic characters, both isolated hard parts and internal anatomy, are provided for two genera in the Dondersiidae. Five species are described or redescribed and earlier descriptions corrected and enhanced. Three belong to Dondersia: D. festiva Hubrecht, D. incali (Scheltema), and D. namibiensis n. sp., the latter differentiated unambiguously from $D$. incali only by sclerites and copulatory spicules. Two species belong to Lyratoherpia: $L$. carinata Salvini-Plawen and L. californica (Heath). Notes are given for other species in Dondersiidae: L. bracteata Salvini-Plawen, Ichthyomenia ichthyodes (Pruvot), and Heathia porosa (Heath). D. indica Stork is synonymized with $D$. annulata. A cladistic morphological analysis was conducted to examine the utility of hard parts for reconstructing solenogaster phylogeny. Results indicate monophyly of Dondersia and Lyratoherpia as described here.
\end{abstract}

\footnotetext{
Received 20 March 2011; accepted 15 May 2012.

* To whom correspondence should be addressed. E-mail: ascheltema@ whoi.edu

$\dagger$ Deceased.
}

\section{Introduction}

The cylindrical, vermiform, sclerite-covered Aplacophora has been a perplexing taxon of molluscs ever since the first two species, representatives of the only two clades, were discovered: Chaetoderma nitidulum Lovén, 1844, Caudofoveata ( $=$ Chaetodermomorpha Pelseneer) and NeOmenia carinata Tullberg, 1875, Solenogastres (=Neomeniomorpha Pelseneer). The puzzle was first of all whether they were molluscs at all, because $N$. carinata lacks a radula, and the radula of $C$. nitidulum is a strange, 2-denticled affair attached to a long cuticular cone. Indeed, the great malacologist Johannes Thiele, with far less information than is now available, and who published over 20 aplacophoran species descriptions, concluded that aplacophorans were not molluscs as such, but phylogenetically between annelids and molluscs and ancestral to the latter (Thiele, 1913c; Glaubrecht et al., 2005). More usually, Aplacophora was placed with the Polyplacophora as Aculifera or Amphineura (see especially Hoffman, 1949). No one now disputes their molluscan nature.

The next puzzles were two questions: Are the aplacophoran Solenogastres and Caudofoveata monophyletic or diphyletic? Are they plesiomorphic, positioned at the base of the mollusc tree, or are they derived? These two questions remained unresolved for many years, whether using comparative descriptive morphologies (e.g., Scheltema, 1993), descriptive embryology (Okusu 2002; Nielsen et al., 2007; Todt and Wanninger 2010), cladistics (e.g., Haszprunar, 2000), or molecular phylogenetics (e.g., Passamaneck, 2003; Giribet et al., 2006; Wilson et al., 2010). However, Sigwart and Sutton (2007) conducted a cladistic morphological analysis including polyplacophoran fossils and, for the first time, resolved a monophyletic Aculifera as Apla- 
cophora plus Polyplacophora. Additionally, the weight of evidence from recent molecular studies (Kocot et al., 2011; Vinther et al., 2011; and Smith et al., 2011) is also in favor of a monophyletic Aplacophora that is recovered with Polyplacophora as a clade we call Aculifera. Earlier hypotheses are reviewed in their papers, as well as in Ponder and Lindberg (2008, Chapters 2 and 4).

Within Aplacophora, the separation of Caudofoveata from Solenogastres (which was the original name for both groups, e.g., Thiele, 1913c) and the membership of species in one or the other remains stable and unquestioned. However, relationships particularly within Solenogastres remain unresolved. An early study of the Antarctic and Subantarctic Solenogastres (Salvini-Plawen, 1978) was the first to arrange families into orders, but without cladistic analysis and with internal hard parts-radulae and copulatory spiculesdescribed from histologic material, not from isolated, entire hard parts. A later morphologic cladistic analysis by Salvini-Plawen (2003b) failed to recover two recognized orders and several families as monophyletic, suggesting either the failure of the existing taxonomy to reflect the evolutionary history of the group or a lack of appropriate signal in the analyzed data. Notably, Salvini-Plawen himself states "the available characters are extremely homoplastic and that homology decisions are far too uncertain to accept the resulting trees as reflections of the phylogeny of the Solenogastres." Therefore, studies of entire internal hard parts are desirable to provide additional characters to evaluate solenogaster evolution.

Here we present new codable morphological characters of two genera in the Solenogastres family Dondersiidae (see Table 2), both for body shape and isolated hard partssclerites, radulae, and copulatory spicules-and for internal anatomic characters, particularly those broadly applicable to Solenogastres. The importance of hard parts for taxonomy has been stressed earlier (Scheltema and Schander, 2000, 2006). The intention here is to provide informative characters for cladistic analyses, eventually leading to a better understanding of relationships among Solenogastres, between Solenogastres and Caudofoveata, among clades within Mollusca and Lophotrochozoa, and with the fossil record.

We describe or redescribe five species of Dondersiidae. Three species belong to Dondersia. One expands the description of the nominate species, D. festiva Hubrecht, 1888, including radula morphology, ventrolateral foregut glands, and descriptions and illustrations of the reproductive system. The second emends and expands the original illustrative material and description of D. incali (Scheltema, 1999), correcting the earlier interpretation of the upper reproductive system. The third describes $D$. namibiensis $\mathrm{n}$. sp. Two species belong to Lyratoherpia. For $L$. carinata SalviniPlawen, 1978, the nominate species, the illustrative material is expanded and the description of the reproductive system emended. A reexamination of the type histologic slides of D. californica (Heath, 1911) indicates that it is a second Lyratoherpia species. Notes are given for other species putatively belonging to the two genera under discussion or to the Dondersiidae: D. annulata Nierstrasz, $1902 ; D$. indica Stork, 1941; L. bracteata Salvini-Plawen, 1978; Ichthyomenia ichthyodes (Pruvot, 1890); and Heathia porosa (Heath, 1911).

Additionally, using detailed morphological data collected from these two genera of Dondersiidae (summarized in Table 2) plus two outgroup taxa, we conducted a cladistic morphological analysis to examine the utility of characters related to hard parts and body shape and proportions in reconstructing Solenogastres phylogeny.

\section{Materials and Methods}

The numbers of individuals of each species range from 147 entire specimens of Dondersia namibiensis sp. nov. to two D. festiva (sectioned) and one Lyratoherpia californica (sectioned). Descriptions of internal anatomy are based on older, rather thick histologic sections of $D$. festiva and $L$. californica and on newly prepared histologic sections at $2 \mu \mathrm{m}$ (Epon-embedded, Richardsonstained) or $7 \mu \mathrm{m}$ (wax-embedded, hematoxylin and eosin-stained) for specimens of $D$. namibiensis, $D$. incali, and $L$. carinata. Photographic images were made with MD-290 Kodak, Nikon 5400, or Canon A650 IS digital cameras with a Zeiss microscope attachment and enhanced in Photoshop. Except for D. festiva and L. californica, radulae and copulatory spicules were isolated with warm potassium hydroxide or with sodium hypochlorite (standard household bleach) and thoroughly washed after dissecting anterior and posterior ends. Scanning electron microscope (SEM) and light microscope (LM) images and drawings were made of entire specimens, sclerites, and radulae (D. incali, D. namibiensis, LM, SEM; L. carinata, LM) and SEM or LM images of copulatory spicules (D. namibiensis, L. carinata, SEM; $D$. incali, LM). The radula and copulatory spicules of $D$. festiva were interpreted from histologic sections of two individuals.

All material examined is on deposit at Muséum National d'Histoire Naturelle (MNHN, Paris); National Museum of Natural History-Naturalis (NNM, Leiden); Smithsonian Institution, National Museum of Natural History (USNM, Washington, DC); and California Academy of Sciences (CAS, San Francisco).

The cladistic morphological analysis was conducted using PAUP 4.0 beta 10 . All 36 characters were treated as unordered, and no weighting was used. Bootstrapping was conducted with 100 replicates. 
Synonymous anatomical terms, sclerite descriptions, and spellings

Terms used here are listed alphabetically outside the parentheses; those within parentheses are alternatives found in the literature: copulatory spicules (copulatory stylets); epidermal sclerites (spicules); lower gametoducts (spawning ducts, shell gland); mantle cavity (pallial cavity); monostichous radula (monoserial) [one tooth per row]; radula sac (radula sheath); upper gametoducts (pericardioducts); vestibule, vestibular (atrium, atrial); ventrolateral pharyngeal foregut glands (ventral salivary glands).

Epidermal sclerite terms used here are scales = flat, small, with or without raised rim, may be adpressed or raised; rods = elongate, either flattened, ovate, or circular in cross-section, raised; trowel-like $=$ with a rim, U-shaped in cross-section, and a stem; skeletal = entirely within cuticle.

\section{Taxonomy \\ Dondersiidae Simroth, 1893}

Heath, 1911: p. 48

Salvini-Plawen, 1978: pp. 23, 27

García-Álvarez and Salvini-Plawen, 2007: p. 82

There are at present no unique identified synapomorphies or thoroughly characterized mosaic for the family. Dondersiidae comprises nine genera and 32 species (Table 1) on the basis of a thin cuticle without skeletal sclerites or epidermal papillae (not unique to this family), and by varying combinations of characters: body with or without posterior end drawn out into fingerlike projection; with two or more types of raised (not adpressed) solid sclerites or one type of adpressed scales; radula monostichous with two or more denticles per row, the central two fused or not fused distally, or radula lacking; ventrolateral foregut glands as groups of extraepithelial unicellular gland cells ("follicles") or as multicellular glands ("type A"); and with or without copulatory spicules. Morphology of reproductive systems is generally species-, not genus-, specific. Because of these difficulties at the family level, the diagnoses of genera are here fully explicit for the species known. They can be easily emended as members of the family become more fully characterized.

\section{Dondersia Hubrecht, 1888}

Type species: Dondersia festiva Hubrecht, 1888 by monotypy.

Simroth, 1893: pp. 323-324

Heath, 1911: p. 48

Salvini-Plawen, 1978: p. 27

García-Álvarez and Salvini-Plawen, 2007: p. 82

\section{Diagnosis}

Elongate, without keel, higher than wide, anterior end tapered to beaklike point, posterior end fingerlike above posteroventral body lobe (lacking in immatures) containing glands and unpaired copulatory spicule with several small accessory scales in paired proximal ventral groups; mouth opening ventral at vestibule entrance; pedal groove with single ciliated ridge ending on posteroventral body lobe, pedal pit glands extending no farther dorsally than body midline; sclerites not adpressed, in single layer, three or more major types with both rods and scales throughout scleritome; epidermis thicker than thin epidermal mantle cuticle; origins of lateral and pedal nerve cords separate; without large paired ventral longitudinal muscles; radula monostichous with two central denticles fused and curved distally and two lateral, outswung, curved denticles arising from rounded base bearing row of denticle-like serrations; paired exoepithelial ventrolateral foregut glands with nonmuscular lobes and extraepithelial gland cells emptying through long necks into muscular, paired ducts becoming fused, single duct (Handl and Todt, 2005, for terminology; one kind of Type A, Salvini-Plawen, 1978); midgut sacculate; cnidariovorous; paired seminal receptacles present or absent; seminal vesicles with two lobes per pair; mantle cavity shallow between fingerlike projection and posteroventral body lobe, without respiratory papillae or folds; with or without dorsoterminal sensory organs.

\section{Geographic distribution and depth range}

Depth range Continental Shelf-Upper Continental Rise, 55-2091 m. Mediterranean 60-65 m; eastern Atlantic: West European Basin 2091 m, Cape Basin off Namibia 619-1007 m; western Pacific: off Indonesia 55 m; Antarctica: Ross Sea 659 m, off South Shetland Is. 300 m, off Graham Land.

\section{Dondersia festiva Hubrecht, 1888}

(Figs. 1-22)

Hubrecht 1888, pp. 324-339, pl. 8-9

Nierstrasz 1905, pp. 676-679, figs. 50-59

van Lummel 1930, figs. 21, 22

Nierstrasz and Stork 1940, pp. 15-21, pl. II figs. 23-54, pl. XV fig. 3

Type material: Holotype: eight slides labeled No. 75 NNM. "Catalogus der Solenogastres" of Nierstrasz indicates No. 75 is the specimen drawn by De Groot for the memorial volume for Prof. Donders (Fig. 1). Hubrecht's figures of the histologic sections match the sections of No, 75 (except that a single figure can bring together anatomical details from more than one section).

Type locality: Secca Benda Palumbo, northern Gulf of Naples, $60 \mathrm{~m}$. No date, but in the mid-1880s.

Other material: Two specimens from the environs of Naples, both sectioned by Nierstrasz: (1) NNM No. 74, six slides of a 10.5-mm specimen collected near Capri, $65 \mathrm{~m}$, 
2.iv.1886 described by Nierstrasz (1905); (2) No. 24 NNM (from J. W. Spengel in 1903), sectioned by Nierstrasz in 1906, not examined by us, not illustrated by Nierstrasz. A fourth specimen taken near Naples is doubtfully D. festiva (NNM No. 40, 17/ii/1905, $60 \mathrm{~m}$, not sectioned), also not examined by us. Both the holotype and No. 74 were reexamined by van Lummel (1930). Hubrecht (1888: p. 2, pl.VIII) indicated that specimens had been sent to him in 1885 and 1886 from Naples; it is unclear whether his original description was based on the external characters of both or just on the sectioned specimen, and No. 74 is not necessarily a syntype (J. Goud in litt., 1999).

Geographic distribution and depth range: Mediterranean off western Italy; Continental Shelf 60-65 m.

\section{Diagnosis}

With characters of the genus. Differentiated by large body size (length $\sim 10 \mathrm{~mm}$ ) and violet color in life; trowellike sclerites with long stems; vestibular papillae up to 4-5 per root; seminal vesicles with two short lobes opening into narrow upper gametoducts; large seminal receptacles with long ducts opening into paired lower gametoducts that fuse shortly after junctions of seminal receptacles and upper gametoducts into single gametoduct filling more than $1 / 2$ posterior end of body. Two dorsoterminal sense organs.

\section{Description}

We based our examination of two histologic slide series (holotype and No. 74 NNM) and literature (Hubrecht, 1888, text and figures; Nierstrasz, 1905, radula; Nierstrasz and Stork, 1940, text and figures) as well as Nierstrasz catalogue in the NNM. Where our examination differs from Nierstrasz's and Stork's descriptions, we have used our observations. Whenever our examinations of slides were unclear about an organ, we used the older literature.

Body (Figs. 1, 2): Body elongate, $\sim 10 \times 1 \mathrm{~mm}$, glistening, violet in life, higher than wide anteriorly (height $0.6-$ $0.8 \mathrm{~mm}$, width $0.4-0.6 \mathrm{~mm}$ ) and posteriorly (height to 1.0 , width $0.8 \mathrm{~mm}$ ) (measured from sections); beaklike anterior end, ambiguous in Figure 1 (from Hubrecht, 1888), although unambiguous in outline sketch of No. 74 accompanying Nierstrasz's catalogue (Fig. 2); ventral body lobe distinct; scleritome rough, sclerites raised.

Epidermal sclerites: Of three types (Fig. 3) (Hubrecht, 1888; fig. 2a), no sclerite slide exists: trowel-like with long stem, $0.05 \times 0.01 \mathrm{~mm}$, especially in proximity of ventral groove (Fig. 3a); short rods (Fig. 3b); and ovate with a short stem (Fig. 3c). Other types possible, e.g., from beside pedal groove.

Cuticle and epidermis: Epidermis 16-18 $\mu \mathrm{m}$ anterodorsally, cuticle $2-4 \mu \mathrm{m}$. Glands of epidermis obvious (van Lummel, 1930, figs. 21, 22).

Anterior internal anatomy: Vestibular papillae numerous, filiform, up to 4-5 per root; supravestibular glands present. Mouth opening ventral at vestibule entrance. Pharynx narrower than oral tube, with many folds (Figs. 8, 9) and subepithelial glands in lobes opening dorsally, with one (?) set of strong circular muscles. With single anterodorsal midgut cecum. Esophagus short with circular musculature. Pedal pit glands restricted to lower $1 / 3$ of body; pedal pit small, $0.3 \mathrm{~mm}$ transversely, $<1 / 2$ ventral body width; one footfold throughout. Cerebrum large, connectives separate. Dorsal blood sinus large, running to cerebrum. Bodywall musculature thin, in three bands: circular, two sets of oblique and thinly spaced longitudinal bands. Without ventral pair of longitudinal muscles. Paired gonads separated by large dorsal sinus, anteriormost as testes.

Ventrolateral foregut glands (Figs. 4, 6, 8): Glands exoepithelial, paired, with densely packed lobes of extraepithelial cells located far dorsally lateral to foregut and ventrally beneath foregut; lobes surrounded by thin layer of connective tissue, glandular cells with long necks without sheath leading ventrally from lateral lobes and dorsally from ventral lobes passing through thick outer muscle layer of short, ventrolateral aglandular ducts; ducts narrowing, becoming fused before entering foregut below radula sac.

Radula (Figs. 4-11; cf. Figs. 50, 52, 53): Small, teeth $\sim 40 \mu \mathrm{m}$, few rows (about 8), paired medial denticles fused nearly their total length with furrow marking line of fusion (Figs. 6, 9, 10), ending in fine, downwardly curved distal point (Figs. 7, 11); paired lateral denticles swung outward (Figs. 4, 5, 9), distally pointed, curved downward (Figs. 7, 11). Base platelike, with denticle-like serrations, centralmost largest (Figs. 6, 10).

Midgut (Fig. 12): Sacculate, with unpaired dorsal cecum, holototype sections filled with cnidarian tentacles and nematocysts.

Posterior internal anatomy and reproductive system (Figs. 13-22): Gonopericardial ducts entering pericardium dorsally somewhat posterior to anteriormost end of pericardium. Pericardium voluminous, $0.5 \times 0.5 \mathrm{~mm}$ at greatest height and depth, containing large mature ova $>0.1 \mathrm{~mm}$, diminishing posteriorly and laterally to narrow tubes opening into upper gametoducts; upper gametoducts running anteroventrally, opening on lateral sides of paired lower gametoducts just posterior to their junction with seminal receptacle ducts; two short, narrow seminal vesicle lobes open into upper gametoducts close to their junction with pericardium, probably through a single duct (Hubrecht, 1888; Stork in Nierstrasz and Stork, 1940) (but not so drawn in Fig. 22). Paired seminal receptacles large, long sacs; duct openings near anterior end of sacs, narrow, running posteriorly along lateroventral walls of seminal receptacles; opening into anterior ends of lower gametoducts some distance beyond seminal receptacles. Lower gametoducts united immediately beyond junction with upper gametoducts filling most of internal body space before emptying 
broadly into shallow mantle cavity. Mantle cavity respiratory folds/papillae lacking. Two dorsoterminal sense organs distinguished by Nierstrasz (1902, 1905), Nierstrasz and Stork (1940), and van Lummel (1930), but not by Hubrecht (1888) or here.

Copulatory spicules and sac (Fig. 20, 21; cf. Figs. 41-44, 54, 55): Sac single, within posteroventral body lobe as ventral invagination of mantle epithelium opening dorsally into mantle cavity. Copulatory spicule gland distinguishable. "Ghosts" of calcareous copulatory apparatus (presumably their thin organic cover) indicating single copulatory spicule extending dorsally into mantle cavity, with numerous accessory bodies in paired lumina of sac.

\section{Remarks}

Understanding the radula and copulatory spicules in $D$. festiva, the nominate species of Dondersia, is important to the definition of the genus Dondersia. We were guided in interpreting histologic sections of internal hard parts in $D$. festiva-copulatory spicules and radula-by comparing them with isolated radulae and copulatory spicules of $D$. incali and D. namibiensis (Figs. 30, 41-44, 54, 55 for copulatory spicules; Figs. 47-50, 52, 53 for radula).

The radula of $D$. festiva was originally typified as having a single pair of long, slender denticles fused distally, and beneath them, a serrate, denticulate bar (not a flat base plate) (Hubrecht,; 1888; Nierstrasz, 1905: figs. 50-54, NNM No. 74; figs. 55-59, NNM No. 75, holotype; reprinted in Nierstrasz and Stork, 1940). Nierstrasz's drawn figures indicate that he did not see, or understand, the outswung parts of the denticles or the plate-like base (Fig. 7), and did not draw radula parts from the sections figured here (Figs. 4-7, 9-11).

Dondersia incali (Scheltema, 1999)

(Figs. 23, 25-28, 33, 34, 36, 49, 53-55) 6

Lyratoherpia incali Scheltema, 1999, figs. 1c, e, 3c, d, 5,

Type material: Holotype (original designation) and paratypes as histologic sections, radula and copulatory spicules slides, not numbered or with catalog number (MNHN); paratype no. 2, MNHN.

Type locality: West European Basin between Hebrides and Scotland, $57^{\circ} 59.7^{\prime} \mathrm{N}, 10^{\circ} 39.8^{\prime} \mathrm{W}, 2091 \mathrm{~m}$ (INCAL DS01, 15/vii/1976).

Other material: In collection of AHS from type locality. Geographic distribution and depth range: Type locality.

\section{Diagnosis}

With characters of the genus. Small, length $<5 \mathrm{~mm}$, greatest height anterior and at posteroventral lobe; scleritome rough but glistening; epidermal sclerites rimmed, sharply pointed scales, flattened rods longer and thicker than scales, and a few rimmed, trowel-like sclerites with a short stem; copulatory spicule single, with a short sheath; glandular copulatory sac voluminous, filling the posteroventral body lobe; paired seminal vesicles each with two unusually large lobes and common duct; without seminal receptacles; lower gametoducts narrow, fused in distalmost portion and opening into mantle cavity.

\section{Description (emended and expanded)}

Body (Figs. 33, 34): To $4.4 \mathrm{~mm}$ long, scleritome rough but glistening; anterior height to $0.5 \mathrm{~mm}$, tapering posteriorly to narrowest part of body, $0.3 \mathrm{~mm}$ just before posteroventral lobe; height at posteroventral lobe to $0.4 \mathrm{~mm}$; contracted pedal pit indistinct, pedal groove extending onto posterior ventral lobe.

Epidermal sclerites (Figs. 34, 36): Three types: scales most numerous, rods, and few trowel-like. Scales rounded basally with wide rim, sides convex proximally, changing distally to straight or concave without rim, tapered to sharp point, to $20 \mu \mathrm{m}$ long, $13 \mu \mathrm{m}$ wide over most of body, posteriorly with longer points, to $35 \mu \mathrm{m}$ long, $2 \mu \mathrm{m}$ or less in thickness except for thicker rims (Fig. 36 no. 7: last two on right common type; first on left is from posterior body); rods much longer than scales (Figs. 34, 36 no. 6), thickest proximally, some with shallow trough or ridge distally, to $100 \mu \mathrm{m}$ long, $9 \mu \mathrm{m}$ wide, $5 \mu \mathrm{m}$ thick, most only $2-3 \mu \mathrm{m}$ thick; some rimmed trowel-like sclerites (not illustrated) with a short stem as in Figure 35 no. 4 for D. namibiensis, narrower and thinner $(2 \mu \mathrm{m})$ than rods, with a distal point. Scales from beside pedal groove (Fig. 36 no. 8) large relative to body scales, $52 \mu \mathrm{m}$ long, $20 \mu \mathrm{m}$ wide, and $4 \mu \mathrm{m}$ thick at rim, curved above short, straight-sided base.

Cuticle and epidermis: Epidermis 7-8 $\mu \mathrm{m}$, cuticle $5 \mu \mathrm{m}$, epidermal glands distinct, scattered.

Anterior internal anatomy: Pedal pit shallow, $<1 / 2$ body width; foot single ridge $30 \mu \mathrm{m}$ at widest; mouth opening ventrally at vestibule entrance; body wall musculature with weak circular and longitudinal fibers, the latter thickest ventrally; vestibular papillae one per root, few, vestibular ciliation with two lateral tracts united posteriorly in Ushape, without frontal extension; pharynx surrounded by circular muscles; large paired anteroventral ganglia $45 \mu \mathrm{m}$ in diameter, posterior to pedal pit, with two commissures; cerebral ganglion $100 \mu \mathrm{m}$ wide, $70 \mu \mathrm{m}$ high; pharynx 65 $\mu \mathrm{m}$ long, surrounded by musculature and intercellular glands; no esophagus; unpaired, short midgut cecum. Buccal ganglia $30 \mu \mathrm{m}$ in diameter below radula sac.

Ventrolateral foregut glands: Exoepithelial, lobate, extraepithelial glandular cells and necks not surrounded by muscles; paired ducts becoming fused before entering foregut.

Radula (Figs. 49, 53): With 8 rows, teeth small, base $\sim 40 \times 40 \mu \mathrm{m}$ wide with denticle-like serrations, entire 
tooth $50 \mu \mathrm{m}$ high, with two medial denticles, fused most of the way, ending in sharp point, deeply curved downward and posteriorly. Pair of outswung denticles distally sharply pointed and curved like medials, not reaching height of medials.

Midgut: With numerous nematocysts; weakly sacculate.

Posterior internal anatomy and reproductive system: Posterior superior ganglia $20 \mu \mathrm{m}$ in diameter, suprarectal commissure $\sim 70 \mu \mathrm{m}$ wide laterally, just below posterior end of pericardium at beginning of upper gametoduct far in front of rectal opening. No posterodorsal sensory organ recognized.

Reproductive system (Figs. 23, 25-28): Mature ova 90 $\mu \mathrm{m}$. Gonopericardial ducts opening dorsofrontally into pericardium, pericardium opening terminally into upper gametoducts; common duct of two, unusually large seminal vesicle lobes, opening on each side dorsally into proximal third of upper gametoducts. Upper gametoducts opening into anterior end of narrow lower gametoducts; lower gametoducts continuing paired for $4 / 5$ of their length, fusing and opening ventrally into anterior mantle cavity. Mantle cavity with scattered glands above epidermis; small, shallow, crowded by posteroventral body lobe containing copulatory spicule and sac.

Copulatory spicules and sac (Figs. 23, 28, 54, 55): Sac unusually large, highly glandular, surrounded by circular muscles, filling posteroventral body lobe, opening anteriorly and ventrally into mantle cavity. Copulatory spicule $>150$ $\mu \mathrm{m}$ long with $80 \mu \mathrm{m}$ long sheath proximally collared; spicule deeply grooved, or trough-like, tapering distally from broad, proximal end; small, paired group of anteroventral, proximal accessory spicules $40 \mu \mathrm{m}$ in length.

\section{Remarks}

The original description of $D$. incali as a species of Lyratoherpia was based on radula morphology similar to that in L. carinata (cf. Fig. 53 with Figs. 45, 46, 51). The upper reproductive system was misinterpreted from histological slides that were too thick and is corrected here by phtographs of slides cut at $2 \mu \mathrm{m}$ (Figs. 25-28) and reconstruction (Fig. 23) provided by Prof. Luitfried v. SalviniPlawen.

Dondersia namibiensis sp. nov.

(Figs. 29-32, 35, 37-44, 47, 48, 50, 52)

Type material: Holotype USNM 1184106 (alcohol specimen, spicule slide) original designation. Four paratypes USNM 1184110 (dissected for radula, copulatory spicules, sclerites; histologic sections labeled A-D).

Type locality: Cape Basin off SW Africa, $23^{\circ} 00^{\prime} \mathrm{S}$, $12^{\circ} 58^{\prime} \mathrm{E}, 619 \mathrm{~m}$ (RV Atlantis II cruise 42 stn 188, 16/v/ 1968).

Other paratypes: About 125 from type locality, USNM
1184107; 7 from $23^{\circ} 00^{\prime} \mathrm{S}, 12^{\circ} 45^{\prime} \mathrm{E}, 1007 \mathrm{~m}$ (RV Atlantis II cruise 42 stn 189, 16/v/1968) USNM 1184108; 1 from $23^{\circ} 05^{\prime} \mathrm{S}, 12^{\circ} 45^{\prime} \mathrm{E}, 974 \mathrm{~m}$ (RV Atlantis II cruise 42 stn 190 , 17/v/1968) USNM 1184109.

Geographic distribution and depth range: Cape Basin between 619 and $1007 \mathrm{~m}$.

Etymology: From the type locality off Namibia southwest Africa.

\section{Diagnosis}

With characters of the genus. Internal anatomy like that of $D$. incali. D. namibiensis differentiated from $D$. incali by sclerites of four types: semitriangular plectron-like scales and flattened rods most prevalent, small rimmed semi-oval scales, and grooved trowel-like scales with short stem; and by morphology of copulatory spicule: single elongate piece plus proximal scales.

\section{Description}

Body (Figs. 31, 32, 37, 39): With bulbous posteroventral lobe and beaklike anterior end. Holotype body length 3.7 $\mathrm{mm}$, height at anterior end $0.4 \mathrm{~mm}$, just before posteroventral lobe $0.4 \mathrm{~mm}$, at posteroventral lobe $0.6 \mathrm{~mm}$; Figure 31 (SEM) length $2.6 \mathrm{~mm}$, heights at anterior end $0.3 \mathrm{~mm}$, just before posteroventral lobe $0.2 \mathrm{~mm}$, and posteroventral lobe $0.3 \mathrm{~mm}$; lengths of individuals from type locality 1.5-5.6 $\mathrm{mm}$. Scleritome texture rough, sclerites raised obliquely, parallel to longitudinal body axis (Fig. 32), posteriormost sclerites like rest of scleritome. Pedal pit and pedal groove often not obvious (but small pedal pit everted in holotype, Fig. 37); footfold ending well onto posteroventral lobe (footfold in Fig. 39 incorrectly not drawn on posteroventral lobe).

Epidermal sclerites (Figs. 35, 40): Four types (not including those beside foot groove): (1) semitriangular, plectronlike scales predominant (Figs. 35 no. 1, 40b) with convex sides, distal point, and thin basal rim, to $25 \mu \mathrm{m}$ long, widest at base, to $17 \mu \mathrm{m}$, and thin, $1 \mu \mathrm{m}$, a few near pedal groove with elongated points; (2) elongate, narrow, flattened rods next most common (Figs. 35 no. 2, 40d), most straight, some slightly curved, scarcely tapered with rounded distal point and rounded to flattened base, to $67 \mu \mathrm{m}$ long, $11 \mu \mathrm{m}$ wide, and $3 \mu \mathrm{m}$ thick, thickest medially (most) or basally in those near pedal groove; (3) small, semi-oval, rimmed scales few (most by pedal groove?) (Figs. 35 no. 3, 40c), to $18 \mu \mathrm{m}$ long, widest basally, to $9 \mu \mathrm{m}$, and $1 \mu \mathrm{m}$ thick, slightly thickened medially at distal end (seen in the light microscope but not SEMs) with numerous, slight, discontinuous axial ridges (seen in SEM); (4) a few trowel-like sclerites with a short stem, $8 \times 2 \mu \mathrm{m}$ (Fig. 35 no. 4); pedal groove sclerites (Figs. 35 no. 5, 40a) basally rimmed (seen in SEMs but not in light microscope), without a distinct, 
narrow root, to $40 \times 10 \mu \mathrm{m} \times 3 \mu \mathrm{m}$ thick at base, with a wide variety of shapes but all convexly curved on one side.

Cuticle and epidermis: Thickness the same dorsally and ventrally; anterior cuticle $4 \mu \mathrm{m}$, epidermis $12 \mu \mathrm{m}$; elsewhere $2 \mu \mathrm{m}$ and $8-10 \mu \mathrm{m}$, respectively; epidermal glands scattered, numerous, single-celled, ovate.

Anterior internal anatomy: Mouth opening ventral at vestibule entrance (Fig. 39). Vestibular papillae stubby, one per root. Mesenchyme present at extreme anterior and posterior ends. Weak body-wall musculature circular and longitudinal. Ventral paired longitudinal muscles absent. Anterior dorsal midgut cecum large, unpaired. Cerebral ganglion oval, not lobed, laterally $87 \mu \mathrm{m}$, height $50 \mu \mathrm{m}$. Origin of lateral and ventral nerve cords separate. Pedal pit glands extending only to midline. Pedal pit $1 / 2$ body width, shallow. Anterior footfold single, broad, narrowing to ridge farther posteriorly and ending well onto posteroventral body lobe.

Ventrolateral foregut glands: Probably as in D. festiva and $D$. incali, but not clear on available torn sections.

Radula (Figs. 47, 48, 50, 52): Teeth about $50 \mu \mathrm{m}$ high, 8 rows. Paired medial denticles fused for most of length, sharply pointed distally and deeply curved ventroposteriorly, arising from flat base, width and height $\sim 40 \times 40 \mu \mathrm{m}$, with thin denticle-like serrations best seen under light microscope, not SEMs (Figs. 50, 52). Pair of outswung denticles distally sharply pointed and curved like medials, not reaching in height as far as medials.

Midgut: Weakly sacculate, filled with nematocysts and cnidarian tentacles with nematocysts still within them.

Posterior anatomy and reproductive system (Figs. 29, 30): Fingerlike projection above posteroventral body lobe filled by mesenchyme. Spermatocyte and yolk material generated in anterior part of gonads, oocyte generation farther posteriorly. Largest egg size about $70 \mu \mathrm{m}$, with large nucleus and intact nucleolus. Ventricle attached to dorsal wall of pericardial cavity; auricles paired. Pericardium large, if filled with gametes stretched laterally nearly to fill body space. Gonopericardioducts enter pericardium dorsoposteriorly. Seminal vesicles paired with two large lobes, both extending far anteriorly to beneath gonopericardioducts; connected to upper gametoduct through a shared duct as in L. incali (Fig. 29) in an early developmental stage; fully developed seminal vesicles packed with gametes, organ relationships distorted. Without seminal receptacles. Paired lower gametoducts narrow, extending far posteriorly before fusing, entering mantle cavity ventral to rectum. Hindgut displaced and broadened by large posteroventral body lobe (Fig. 30). Dorsoterminal sense organ unknown.

Copulatory spicules and sac (Figs. 30, 38, 41-44): Sac large, lumen of unusually large, glandular posteroventral body lobe as in D. incali (Fig. 30). Copulatory spicule unpaired, single, elongate, hollow with one edge rolled over other edge dorsally and proximally (Fig. 44), opening dis- tally to form semi-enclosed tube (Fig. 43); with two proximal groups of anteroventral accessory spicules (Figs. 41, 42), positioned as in Figure 38.

\section{Remarks on D. incali and D. namibiensis}

We consider these two to be sister species. There is great latitudinal distance between them, $9000 \mathrm{~km}$ between $80^{\circ} \mathrm{N}$ and $81^{\circ} \mathrm{S}$, with no known collections in between; the depths at which they were taken, Upper and Lower Continental Slope (619-1007 m for D. namibiensis and $2091 \mathrm{~m}$ for $D$. incali) are not significantly different for deep-sea aplacophoran species in our experience. They are easily differentiated by their hard parts, primarily sclerites and copulatory spicules, but not by internal anatomy. The radula morphology is similar except for larger denticle-like serrations in $D$. namibiensis. Scanning electron microscopy allows a precise means of comparing sclerites of these two sister species. The most common sclerites in both are scales: in D. namibiensis they have thin rims and are plectron-shaped; in $D$. incali they have thick rims and are drawn-out into sharp points; rods, second most common in both species, are shorter in D. namibiensis. Pedal groove sclerites are less deeply curved in D. namibiensis. Unlike incali, the copulatory spicule in namibiensis lacks a sheath and is hollow rather than grooved. There is an apparent lack of seminal receptacles in the two species (but see "Remarks on the genus Dondersia: Seminal vesicles/seminal receptacles" below).

\section{Dondersia annulata Nierstrasz, 1902}

Dondersia annulata Nierstrasz, 1902, pp. 33-36, pl V, figs. 172-179

Nierstrasz, 1905, pp. 676-679, figs. 60-62

Dondersia indica Stork, 1941, pp. 64-70, figs. 32-41

Type material: Holotype slides (and only specimen). Zoological Museum, University of Amsterdam.

Type locality: Bay of Bima, N. Sumbawa, East Indian Archipelago, 55 m (Siboga stn 47, 1899/1900).

Geographic distribution and depth range: Type locality.

\section{Description and remarks}

We synonymize $D$. indica with $D$. annulata, based on the written, similar descriptions and illustrations of Nierstrasz (1902, 1905) and Stork (1941), although we have not examined the type histologic slides. According to GarcíaÁlvarez and Salvini-Plawen (2007: 82) the holotype (and only) specimen of $D$. indica is missing. Both specimens came from the type locality and presumably were in the same dredge haul from station 47 of the Siboga Expedition of 1899/1900, on which Nierstrasz was present (van Berkel, 2012). Both specimens were described from material fixed in absolute alcohol and preserved in 95\% alcohol (Nier- 
strasz, 1902). The color image of D. annulata was made after preservation; perhaps Nierstrasz made color notes of the specimen when it was alive. D. annulata was described within 2-3 years of collection and $D$. indica some 40 years later. For hard parts, most epidermal sclerites of $D$. indica were lacking at the time sectioned; only some rods were present. As rods are thicker in $D$. incali and D. namibiensis (5 $\mu \mathrm{m}$ and $3 \mu \mathrm{m}$, respectively) than scales (1-2 $\mu \mathrm{m}$ and 1 $\mu \mathrm{m}$, respectively), we assume that long preservation time would have dissolved the scales, if present. Sclerite drawings of D. annulata (Nierstrasz, 1902: fig. 173) show rimmed scales (most common), rods and needles, and stemmed forms from beside the foot groove. The radula in each specimen was described and drawn from histologic sections; for D. annulata, diagnostic in Nierstrasz (1905). A copulatory sac was not identified.

Both specimens were in reproductive condition and had the following in common (Nierstrasz, 1902, 1905; Stork, 1941): a body length of 2 or $3 \mathrm{~cm}$ with irregular transverse constrictions; a single pedal fold; thickset filiform vestibular papillae ( $>1$ per root, $D$. indica); the mouth opening and vestibule separate (by the criterion of scleritome present between the vestibule and mouth openings); a small pedal pit; a much-folded pharynx; ventrolateral foregut glands that surround the ducts, which unite; a radula with fused medial denticles only and a base plate illustrated as bars with denticle-like serrations (D. indica Stork, 1941, fig. 36; D. annulata Nierstrasz, 1905, figs. 51, 55, 56, 61; but not Nierstrasz, 1902); a sacculate midgut; paired lower gametoducts that unite, filling a major part of the posterior body space; paired "seminal vesicles" that were identified by Nierstrasz for $D$. annulata, but probably are seminal receptacles, as illustrated for D. indica in Stork (1941, fig. 37); and extrusible dorsoposterior sensory organs.

The species differed from each other in the presence of 30 white external "rings" in $D$. annulata, with no evidence of color bands in $D$. indica after 40 years of preservation. Color bands have been reported for one other Solenogastres species, Anamenia amabilis Saito and Salvini-Plawen, 2010, from off Japan. Stork (1941, fig. 38) illustrates a single, blind ventral "gland" beneath the lower joined gametoducts and connected by a "furrow" to the mantle cavity; we interpret it as a copulatory spicule sac of a single copulatory spicule. Stork presciently considered it part of the reproductive system. A sac is not obvious in the sagittal sections illustrated by Nierstrasz (1902, fig. 178); he, but not Stork, mentions and figures the fingerlike posterior extension of the body. The body of neither species is illustrated to show a posteroventral lobe.

The descriptions of both $D$. annulata and $D$. indica fit the diagnosis of Dondersia except that the ventrolateral extraepithelial foregut glandular cells have no long necks and apparently surround the paired ducts. However, the cells of these glands and those of the pedal pit and pharyngeal glands are not differentiated in the illustrations. Further, the mouth opening is considered to be separate from the vestibule.

\section{Remarks on the genus Dondersia}

There are only three species of Dondersia that establish the characters used in our coding and can be analyzed cladistically: $D$. festiva, $D$. incali, and $D$. namibiensis. The written descriptions of $D$. annulata Nierstrasz and its synonym $D$. indica Stork are not adequate for coding here.

\section{Radula and ventrolateral foregut glands}

The ventrolateral foregut glands of $D$. festiva closely resemble those of Acanthomenia, both having lobes of extraepithelial glandular cells with long, bundled necks that pass through the outer muscle layer of the proximal part of the duct (Figs. 6, 8; cf. Handl and Salvini-Plawen, 2002, figs. 1, 8; Handl and Todt, 2005). The two genera differ, though, in the musculature of these glands, with lobes and necks surrounded by muscles in Acanthomenia but not in Dondersia. Dondersia and Acanthomenia have a monostichous radula, the teeth with four denticles with fused elements arising from a rounded base, although the fused teeth in Acanthomenia are the two lateral pairs (Scheltema, 1999, fig. 3; Handl and Salvini-Plawen, 2002; Gil-Mansilla et al., 2008). There are similarities in rimmed sclerite scales in both, but Acanthomenia has long, hollow needles as well. Notably, the genus-level cladistic morphological analysis of Salvini-Plawen (2003b) recovered Acanthomeniidae in a polytomy with Dondersiidae (in part). The placement of Acanthomenia and Dondersia in separate orders (SalviniPlawen, 1978, Pholidoskepia [Dondersia], Cavibelonia [Acanthomenia]) needs to be revisited.

The fused, single duct that joins the ducts of the paired ventrolateral foregut glands in Dondersia is found in other Solenogastres genera with monostichous and polystichous radulae (Nierstrasz, 1905; Scheltema et al., 2003) and is thus not unique to the Dondersiidae.

\section{Seminal vesicles/seminal receptacles}

The similar reproductive systems of $D$. incali and $D$. namibiensis differ from those of $D$. festiva in size of the lower gametoducts after fusion, size of seminal vesicle lobes, and lack of seminal receptacles. A speculation is that lack of seminal receptacles in the sister species may be more apparent than real, with a separate receptacle (as in $D$. festiva) replaced by certain sections of epithelia that act as the receptacles in the relatively enormous seminal vesicle lobes. These lobes are filled by sperm with no particular arrangement (as found in seminal vesicles) and by areas of epithelium with attached sperm heads organized with the tails inward into the lobe (as found in seminal receptacles). 
It would be a matter of finer microscopy than presented here to ascertain how the vesicle lobes might function in the two species vis-a-vis D. festiva. It is plausible that the large, shallow-water $D$. festiva has space for large seminal receptacles but the smaller, deep-sea $D$. incali and D. namibiensis, with less body space for separate organs, incorporate two functions in the enlarged lobes of the upper gametoduct. The arrangement does not necessarily deny membership in Dondersia.

\section{Taxonomic characters}

D. namibiensis and the closely related sister species $D$. incali are placed in the genus that includes $D$. festiva on the basis of anterior and posterior body shape, the anterior end beaked and the posterior end with a drawn-out "finger" above a ventral body lobe; the sclerites in a single raised layer, with rimmed scales, some trowel-like with stems, and rods; pedal pit glands that extend dorsally to the body midline; the size of the pedal pit, less than $1 / 2$ body width; the radula with two medial fused denticles, two outswung denticles, and serrations on the base plate; the ventrolateral foregut gland morphology (shared with Lyratoherpia); and an unpaired copulatory spicule with attendant proximal spicules within the lumen of the posteroventral lobe.

\section{Other species of Dondersia}

For the remaining species of Dondersia (Table 1), there are three Antarctic species described. D.? cnidevorans, D.? laminata, and D.? stylastericola, all Salvini-Plawen, 1978, were each described from a single specimen and placed provisionally in Dondersia by the author, who considered that $D$. laminata and $D$. stylastericola may be synonymous. D. californica Heath is moved here to Lyratoherpia (see below).

\section{Lyratoherpia Salvini-Plawen, 1978}

Type species: Lyratoherpia carinata Salvini-Plawen, 1978:

34 , by original designation

Lyratoherpia? bracteata Salvini-Plawen 1978: p. 37

García-Álvarez and Salvini-Plawen, 2007: p. 87

\section{Diagnosis (emended)}

Elongate, carinate, rounded anteriorly and posteriorly, with posteroventral body lobe; sclerites in single layer, raised, mainly rimmed scales and flattened rods; cuticle thinner than epidermis; mouth opening not separate from vestibule opening; pedal pit glands massive, meeting middorsally; radula monostichous with four denticles, the medial pair fused distally, the lateral pair outswung, radula base with two medial ribs extending from lateral denticles; ventrolateral foregut glands in lobes surrounding pharynx, form as in Dondersia; hemocoel filled by mesenchyme; seminal vesicles paired with several lobes sharing single duct; with seminal receptacles; with paired copulatory spicules; posteroventral body lobe filled by mesenchyme, no lumen or gland present; paired lower gametoducts uniting before emptying into mantle cavity; mantle cavity with numerous folds; dorsoterminal sense organ present.

\section{Geographic distribution and depth range}

Western Antarctica; off California; Continental shelf and Upper Slope depths, 38-714 m.

Lyratoherpia carinata Salvini-Plawen, 1978 (Figs. 45, 46, 51, 56-71)

Salvini-Plawen, 1978: pp. 34-37, figs. 9-12, 272

García-Álvarez and Salvini-Plawen, 2007: p. 87

Type material: Holotype, USNM 1184102 (14 histologic slides, 1 sclerite slide). Paratypes, subsequent designation, no. 1, USNM 1184103 (entire figured alcohol specimen, 2 sclerite slides); no. 2, USNM 1184104 (dissected specimen, copulatory spicule slide, sclerite slide; figured radula lost); no. 3, USNM 1184105 (13 histologic slides, 2 sclerite slides) (some paratype slides labeled "paralectotype") one unnumbered, USNM 749724 (alcohol specimen).

Type locality: Ross Sea $72^{\circ} 05^{\prime} \mathrm{S}, 172^{\circ} 08^{\prime}-09^{\prime} \mathrm{E}, 344-$ $351 \mathrm{~m}, 9$ individuals (USARP 32- 1996, 10/i/1968exi), of which only 4 have been deposited in USNM.

Other material: 1 individual, USNM 749724 from $71^{\circ} 16^{\prime}-17^{\prime} \mathrm{S}, 171^{\circ} 29^{\prime}-33^{\prime} \mathrm{E}, 659-714$ m (USARP 27-1870, 14/i/1967), not examined.

Geographic distribution and depth range: Ross Sea, Antarctica, Continental Slope $344-714 \mathrm{~m}$.

Remarks: The holotype histologic slides, upon which the original description was based, had not been deposited with the syntypes while this manuscript was being prepared; they were deposited later when they were found and are not illustrated here. Paratype no. 1 was the syntype chosen to be the lectotype and is illustrated here, along with paratype nos. 2 and 3.

\section{Diagnosis (emended)}

Body to $18 \times 1.5 \mathrm{~mm}$; sclerites of three types: rimmed scales broadening distally, ending in a short, scarcely tapered point; numerous short, straight, flattened rods; and a few long, curved, thicker rods. Radula monostichous with four denticles, the medial pair fused and two laterals outswung; paired copulatory spicules with sharp bend and two processes lying in short sac, mostly extended into mantle cavity; foot with two folds anteriorly, becoming single, stout fold, reaching onto posteroventral body lobe; suprapallial glands present; with a retractile patch of specialized epidermis anterior to the dorsoterminal sense organ (Salvini-Plawen, 1978, fig. 11). 


\section{Description (emended and expanded)}

Body (Figs. 56, 57, 61): Holotype not figured. Paratype no. 1, length $6.7 \mathrm{~mm}$, carinate, greatest height anterior, 0.9 $\mathrm{mm}$, width $0.8 \mathrm{~mm}$, posteriormost height $0.8 \mathrm{~mm}$, widths on undistorted sections nearly equal to heights. Greatest body dimensions $18 \times 1.5 \mathrm{~mm}$. Sclerite coat rough, shining; opening of vestibule spade-shaped, reflecting shared opening of mouth and vestibule; pedal pit obvious; contracted mantle cavity opening triangular, between posteroventral lobe and rounded posterior.

Epidermal sclerites (Figs. 58, 59): Three types: (1) scales to $27 \mu \mathrm{m}$ long, proximally rounded, broadest distally, to 16 $\mu \mathrm{m}$, before abruptly tapering to short, broad point, thickly rimmed from base to start of distal taper, thickest distally to $4 \mu \mathrm{m}$ (Figs. 58 no. 1, 59 no. 2); (2) flattened rods about same length as scales, to $25 \mu \mathrm{m}$ long, $7 \mu \mathrm{m}$ wide, $2 \mu \mathrm{m}$ thick, with rounded or slightly tapered distal end (Figs. 58 no. 2, 59 no. 1); (3) longer curved, rounded, thick, narrow rods tapered at each end, to $52 \mu \mathrm{m}$ long $\times 5 \mu \mathrm{m}$ wide $\times 4$ $\mu \mathrm{m}$ thick (Fig. 59 no. 3); sclerites from beside pedal groove curved, $25 \mu \mathrm{m}$ long, $7 \mu \mathrm{m}$ wide, rounded at both ends, to 4 $\mu \mathrm{m}$ thick along convex side, with thin basal rim extending furthest distally on convex side (Fig. 58 no. 3). Distal thickening of scales appearing as slight keel in transmitted light, but not in SEM images.

Cuticle and epidermis (Figs. 62-67): Epidermis 50-60 $\mu \mathrm{m}$ laterally and dorsally, 35-40 $\mu \mathrm{m}$ ventrally, gland cells thickset; cuticle 5-20 $\mu \mathrm{m}$.

Anterior internal anatomy (Fig. 62): With a thick mesenchyme. Sensory papillae of vestibule thickset, filiform, up to $100 \mu \mathrm{m}$ in length, 2-4 sharing single root; with supravestibular gland cells. Pedal pit broad, nearly $1 / 2$ body width, shallow; massive pedal pit glands meeting dorsally above cerebrum. Cerebral ganglion quadrate in frontal sections, $200 \mu \mathrm{m}$ wide $\times 140 \mu \mathrm{m}$ high. Unpaired, short dorsal cecum. Pharynx narrow, with folds and circular musculature, scarcely broadening posteriorly. (For further description see Salvini-Plawen, 1978.)

Ventrolateral foregut glands: Lobes of gland cells nonmuscular, above and beside narrow pharynx, meeting ventrally; gland cells extraepithelial, extending with nonmuscular bundled long necks into paired, narrow ducts (only a portion of necks discerned), ducts remaining paired, opening ventrally below radula.

Radula (one isolated radula examined) (Figs. 45, 46, 51): Seven rows of teeth; medial denticles fused, tips curved downward posteriorly and sharply pointed distally, arising from a flat, nearly oval base plate without denticle-like serrations. Lateral, outswung denticles curved and sharply pointed as in medials, joining proximally and medially, continuing on base plate as two juxtaposed medial ridges.

Midgut: Sacculate; with nematocysts.

Posterior internal anatomy and reproductive system
(Figs. 24, 63-71): With a thick mesenchyme, also entirely filling posteroventral body lobe (Fig. 71). Pericardium small, restricted to narrow part of body beneath carina (Figs. $65,66)$. Gonopericardial ducts long, $\sim 265 \mu \mathrm{m}$ in the 11.5-mm paratype no. 3, emptying laterally into pericardium. Ventricle small, attached to dorsal pericardial wall, crowded by gametes; auricles paired. Upper gametoducts leading ventrally from posteriormost lateral corners of pericardial cavity, then bending $90^{\circ}$ to lead straight anteriorly; at bend, joined by common duct of several ( $\sim 5-6)$ narrow lobes of the seminal vesicles (Figs. 66, 67). Seminal receptacles large, lying anterior to and beneath lower gametoducts (Fig. 63), joining them laterally through short ducts, then continuing for short distance farther posteriorly. Upper and lower gametoducts joining posterior to ducts of seminal receptacles. Paired portion of lower gametoducts wide, surrounded by musculature (Figs. 63-65); paired and fused parts of lower gametoducts together $>1.0 \mathrm{~mm}$ long $(1.5 \mathrm{~mm}$ in paratype no. 3); fused distal part in holotype longer than the proximal paired parts, but in paratype no. 3 distal fused portion shortest, emptying broadly and dorsally into scarcely widened mantle cavity. Mantle cavity wall thrown into numerous respiratory folds; with suprapallial glands lying laterally and dorsally; dorsoterminal sense organ present.

Copulatory spicules and copulatory spicule sac (Figs. 24, 41-44, 60, 68-70): Spicules paired, $\sim 700 \mu \mathrm{m}$ long; copulatory spicule sac short, $\sim 60 \mu \mathrm{m}$, with few gland cells, not within posteroventral lobe but as anterior invagination of ventral mantle cavity pocket ("pallial cavity pocket Prt," Salvini-Plawen, 1978, fig. 12), single but becoming paired posteriorly, emptying ventrally into mantle cavity pouch. Forming, proximal ends of paired copulatory spicules lying within copulatory spicule sac, bending $>45^{\circ}$ at emergence from sac. Copulatory spicules tapered distally, greatest length lying within grooves between mantle cavity folds; with two short processes at bend. Spicules including processes hollow.

\section{Remarks}

The description here of $L$. carinata emphasizes and illustrates external anatomy and all hard parts and describes some of the characters of internal anatomy, particuarly emending the reproductive system. The original description is expanded to illustrate isolated internal hard parts: radula (Figs. 45, 46, 51) and copulatory spicules (Figs. 41-44 SEMs), as well as SEMs of sclerites. A set of histologic sections with nuclear stain (paratype no. 3) adds information to holotype sections without nuclear stain. Unfortunately, anterior histologic sections for both the holotype and paratype no. 3 were damaged and distorted, probably owing to poor initial fixation.

The difference in relative lengths between the paired and 
united portions of the lower gametoducts in paratype no. 3 and holotype sections is probably due to differences in amount of contraction under fixation.

\section{Lyratoherpia californica (Heath, 1911)}

(Figs. 72-75)

Dondersia californica Heath 1911, pp. 155-159; pl. 3 fig. 9, pl. 4 figs. 15 , 18, pl. 5 fig. 4 , pl. 6 fig. 2, pl. 23 figs. $1-8$, pl. 32 fig. 8 , pl. 35 fig. 12

Dondersia californica Heath, García-Álvarez and SalviniPlawen, 2007: p. 82

Type material: Holotype, California Academy of Science, 3 serial section slides.

Type locality: Off San Diego, California, 38-43 m (RV Albatross 4303, 3/i/1904).

Geographic range: Type locality.

\section{Description}

Holotype and only individual described from sections of immature specimen, reexamined here; received by Heath with sclerites lacking, removed by initial fixation. Characters indicating membership of D. californica in Lyratoherpia rather than Dondersia added here to original description.

Body (Heath, 1911, pl. 3 fig. 9, pl. 4 figs. 15, 18): Length $7 \mathrm{~mm}$, height $1.2 \mathrm{~mm}$ (Heath, 1911, p.155); higher than wide except before posteroventral lobe in sections, heights and widths in mm: anterior end $0.8 \times 0.6$, midbody $0.9 \times$ 0.7 , just before posteroventral lobe $0.4 \times 0.4$, and through developing posteroventral lobe $0.5 \times 0.4$; differences in height from Heath's probably due to shrinkage during slide preparation. Body shape somewhat triangular, narrowest dorsally, widest through center; anterior end rounded without beak and posterior end without fingerlike extension (Heath); carinate, carina forming line of dorsal knobs (Fig. 72); pedal pit obvious (Heath), footfold single throughout, pedal groove continuous on developing posteroventral lobe (Fig. 75).

Epidermal sclerites: Unknown; cuticle as drawn by Heath indicating single layer of obliquely raised sclerites.

Cuticle and epidermis: Epidermis $\sim 32 \mu \mathrm{m}$ measured on posterior sections; cuticle, no longer visible on sections, $\sim 9$ $\mu \mathrm{m}$ measured on Heath illustration (1911, pl. 32 fig. 8). Gland cells scattered.

Anterior internal anatomy (Figs. 72, 73): Mesenchyme $0.07 \mathrm{~mm}$ thick filling hemocoel; mouth ventral to vestibule with separate opening, cuticle-bearing epidermis separating them (Heath 1911, pl. 23 figs. 1-3); vestibule with numerous filiform papillae, 3-6 per root according to Heath. Lobes of pedal pit glands large, filling hemocoel above cerebral ganglion, then above and beside foregut, finally emptying into pedal pit $1 / 2$ body width with long cilia. Foot with single fold throughout. Cerebral ganglion $150 \mu \mathrm{m}$ wide $\times 120 \mu \mathrm{m}$ high, lateral and ventral cords leaving separately. Foregut narrow with many narrow folds and a few subepithelial glands, joining short, single dorsal cecum at entrance to midgut. Pharynx with few dorsal salivary glands present according to Heath.

Ventrolateral foregut glands (Fig. 73): Exoepithelial lobes of extraepithelial glandular cells without surrounding muscles ("pyriform gland cells ... with long necks," Heath, 1911: 157) located lateral and ventral to pharynx, with very long, bundled necks without muscular sheath leading ventrally to large, long paired ducts $94 \mu \mathrm{m}$ in greatest diameter with not more than perhaps two surrounding muscle fibers, changing to narrow, nonmuscular (?) ducts $12.5 \mu \mathrm{m}$ in diameter that meet beneath radular sac; ducts may not be fused although having juxtaposed cell walls.

Radula (Fig. 73): Morphology of sectioned radula unclear except for paired median denticles with fused medial tips $\sim 38 \mu \mathrm{m}$ long; base of indeterminable shape and size with neither denticle-like serrations nor paired ridges observed by Heath or by us, nor were outswung denticles. Number of teeth not determined but seem fewer than Heath's count of 12 .

Midgut: Strongly sacculate, with nematocysts.

Posterior internal anatomy and reproductive system (Figs. 74, 75): With thick mesenchyme, thickest ventrally up to $150 \mu \mathrm{m}$. Eleven dorsoposterior sense organs (Heath 1911: 155). Mantle cavity opening each side of and above small, developing posteroventral body lobe filled by mesenchyme. Undeveloped eggs in gonad; long gonopericardial ducts opening laterally into narrow, anterior end of pericardial cavity; pericardium becoming large farther posteriorly (200 $\mu \mathrm{m}$ wide, $150 \mu \mathrm{m}$ high) with large ventricle (120 $\mu \mathrm{m}$ wide, $125 \mu \mathrm{m}$ high) attached broadly to pericardial wall; auricles paired. Upper gametoducts turning anteriorly immediately after leaving posterior end of pericardium. Paired lower gametoducts beginning beneath pericardium anterior to entrance of upper gametoducts. Paired empty spaces defined by thin epithelium, putative seminal receptacles, beginning beneath pericardium anterior to entrance of upper gametoducts into lower gametoducts. Indication of developing seminal vesicle lobes above upper gametoducts (Fig. 74), round nucleated cells within mesenchyme. Lower gametoducts scarcely developed, uniting shortly posterior to their junction with upper gametoducts, united portion large anteriorly, becoming narrower posteriorly before opening into mantle cavity.

Copulatory spicules and sac: Small "cloacal coecum" (Heath, 1911, pl. 6 fig. 2 "co") (Fig. 75, "co") or ventral outpouching of ventral mantle cavity wall, broadening anteriorly into same position as copulatory spicule sac in $L$. carinata just anterior to mesenchyme-filled posteroventral lobe. Heath (1911, p. 158): "in the adult animal ["co"] may develop copulatory spicula or some gland." 
Remarks

Although Dondersia californica Heath lacks discriminating hard parts of sclerites and a clearly sectioned radula, we move it to Lyratoherpia on the basis of internal and external body morphology: carina; rounded anterior end; no fingerlike posterior extension; thick mesenchyme in hemocoel; pedal-pit glands meeting mid-dorsally; mesenchyme-filled posteroventral lobe with no lumen; and a developing copulatory spicule sac anterior to the posteroventral body lobe. The morphologic cladistic analysis supports our decision (Fig. 76).

Lyratoherpia? bracteata Salvini-Plawen, 1978

Salvini-Plawen 1978, pp. 37-39, figs. 13-15

Lyratoherpia bracteata García-Álvarez and Salvini-Plawen, 2007: p. 87

Type material: Holotype histologic sections, 2 slides, no sclerite slide, USNM 749703.

Type locality: South Sandwich Islands, $56^{\circ} 20^{\prime}-56^{\circ} 28^{\prime} \mathrm{S}$, $27^{\circ} 28^{\prime}-27^{\circ} 29^{\prime} \mathrm{W}, 148-201 \mathrm{~m}$, (USARP stn 22-1581, 6/iii/ 1966).

Geographic distribution and depth range: Type locality.

\section{Description}

The type sections, now faded, of the single juvenile twisted specimen have been reexamined.

Body: elongate, length at least $2 \mathrm{~mm}$ (Salvini-Plawen, 1978) without carina; rounded anteriorly, width $150 \mu \mathrm{m}$, height $175 \mu \mathrm{m}$; midbody triangular in cross-section, widest ventrally, $230 \mu \mathrm{m}, 9 \mu \mathrm{m}$ dorsally, height $225 \mu \mathrm{m}$; single foot fold.

Epidermal sclerites (Salvini-Plawen, 1978 fig. 14): Three types: lancet-like $25 \times 8 \mu \mathrm{m}$; knifeblade-like $80 \times 12$ $\mu \mathrm{m}-100 \times 8 \mu \mathrm{m}$; rods $60 \times 6 \mu \mathrm{m}-80 \times 5 \mu \mathrm{m}$; not preserved.

Cuticle and epidermis: To $5 \mu \mathrm{m}$ and $17 \mu \mathrm{m}$, respectively; many epidermal glands.

Anterior internal anatomy: Without thick mesenchyme; mouth not distinctly separated from vestibule; vestibular papillae stubby, few, two per root; pedal pit glands extensive, lobes large, meeting mid-dorsally between dorsal cecum and cerebral ganglion; pedal pit 1/3 ventral body width.

Ventrolateral foregut glands: Lobate, extraepithelial; glandular cells with necks not clearly stained ("ampullae" sensu Salvini-Plawen, 1978).

Midgut: Weakly sacculate.

Radula: Monostichous, 5-6 rows, teeth with four parallel denticles vertical to a base, two medial denticles thin, fused at tips and joined proximally by thickened process at base, lateral denticles thicker than medials, not outswung (Salvini-Plawen, 1978: 38; fig. 13).

Posterior anatomy and copulatory spicules: Unknown.
Remarks

The generic placement of Lyratoherpia? bracteata (a juvenile) is dubious, but has family-level characters of Dondersiidae: more than two types of sclerites, a cuticle thinner than the epidermis, and a radula with two medial denticles fused at tips. Besides lacking the posterior end, it differs from the Lyratoherpia species described here in the triangular body shape without carina; a lack of thick mesenchyme; a radula with thick, vertical, uncurved lateral denticles; and sclerites unlike those of $L$. carinata. It shares with $L$. carinata and $L$. californica massive pedal pit glands that meet mid-dorsally.

\section{Remarks on the genus Lyratoherpia}

The genus Lyratoherpia has not been taken from the Atlantic Ocean or Mediterranean. Of the two known species, $L$. carinata is from the eastern Pacific, and $L$. carinata is from the Ross Sea, Antarctica, open to the Pacific Ocean. They differ from the three species of Dondersia described here by seven well-characterized anatomical differences: (1) a rounded anterior body end; (2) a rounded posterior body end without a fingerlike extension; (3) a body carina; (4) thick mesenchyme-filled hemocoel; (5) copious pedal glands that meet mid-dorsally; (6) mesenchyme-filled posteroventral lobe without a lumen; and (7) copulatory spicules paired, not within posteroventral body lobe (in $L$. carinata, putative for $L$. californica). They share with $D$. festiva the character of several filiform vestibular papillae that arise from a single root, as well as extensive, lobed ventrolateral foregut glands with extraepithelial gland cells emptying into muscular ducts through long necks (known in L. californica, in part for L. carinata). Although morphology of anatomy and hard parts is incompletely known, synonymy of the two Lyratoherpia species is unlikely, with a great latitudinal distance and depth discrepancy between them.

L. carinata was first separated from other dondersiid clades on the basis of the outswung denticles of the radula (Salvini-Plawen, 1978). As shown here, however, the radulae of Dondersia species are like those of $L$. carinata in having four denticles, the medial pair fused at the tip, and the lateral pair outswung. However, the base of the radula in Dondersia species bears denticle-like serrations, lacking in L. carinata and not obvious in L. california sections.

Generic assignment of Lyratoherpia? bracteata is tentative pending new material.

\section{Notes on genera of Dondersiidae other than Dondersia and Lyratoherpia}

Ichthyomenia ichthyodes (Pruvot, 1890) is an incompletely described species in a monotypic genus based on a single specimen, taken from $80 \mathrm{~m}$ off Banyuls in the waters 
of the western Mediterranean. Pruvot (1891) gave an extended description. I. ichthyoides has some characters like those of the five species in Dondersia and Lyratoherpia as given here, some like those of only Dondersia or only Lyratoherpia species, some like neither, and many characters are either not described or ambiguous. Characters that are ambiguous or for which there is no or incomplete information are body dimensions, radula, copulatory spicules, sclerite scales, epidermis/cuticle, ventrolateral foregut glands, copulatory spicule sac (but presence looks likely from illustrations), and sizes/lengths of paired and fused portions of lower gametoducts. Characters that differentiate I. ichthyoides from the dondersiid species described here are a body nearly round in cross-section; lateroventral foregut glands that extend dorsally to beneath the cerebrum and ducts that remain separated, emptying on either side of the radula; adpressed sclerite scales covering body, with rods only beside the foot-groove sclerites; and no anterodorsal cecum of the midgut.

Certainly I. ichthyodes belongs within the Dondersiidae, but its position cannot be determined, and we leave it in its present genus. New collections in the western Mediterranean are needed, both for I. ichthyoides and D. festiva.

The histologic slides of Heathia porosa (Heath, 1911), a sole individual from off California in a monotypic genus, has been reexamined and appears to be unique. The remaining genera-Helluoherpia Handl and Büchinger, 1996 and Squamatoherpia Büchinger and Handl, 1996 (both monotypic), Micromenia Leloup, 1948 (three species), and Stylomenia Pruvot, 1899 (two species); and the speciose Nematomenia Thiele, 1913a, b-are left for future consideration and examination of new material that has been collected recently off Norway (Christiane Todt, University of Bergen Museum, Norway; pers. comm.).

\section{Results of the cladistic morphologic analysis}

To evaluate the utility of characters related to hard parts and body shape, we conducted a cladistic morphological analysis. Of 36 characters, 15 are related to hard parts (e.g., sclerites, copulatory spicules, or the radula) and 9 are related to body shape or proportions. Three equally parsimonious trees were recovered. All recovered Dondersia and Lyratoherpia monophyletic; however, only one recovered Dondersiidae monophyletic. In the other two most parsimonious trees, the outgroup taxon Acanthomenia was placed sister to Dondersia or Lyratoherpia. The 50\% majority rule consensus tree is presented in Figure 76. Dondersia is recovered monophyletic with a bootstrap support value of 91, and D. incali and D. namibiensis are recovered as sister taxa with a bootstrap support value of 85 . Lyratoherpia is strongly supported as monophyletic with a bootstrap support value of 98 .

\section{Discussion}

The family Dondersiidae is a poorly defined taxon with 31 species in 9 genera, 4 of which are monotypic (Table 1 ). Most species have inadequately described hard parts and body shapes and proportions. From our cladistic analysis of Dondersia and Lyratoherpia species, it seems clear that phylogenetic relationships can be understood better by the use of these characters. For those who need to identify aplacophorans (e.g., ecologists, paleontologists, physiologists, phylogeneticists, and malacologists, including those who are aplacophoran taxonomists), aplacophoran taxonomic publications need as many detailed character descriptions as possible besides soft anatomy. Such characters are listed in Table 2.

In some cases, histologic sections may need to be made, or are the only material in museums. A radula is absent in about $20 \%$ of solenogaster genera (Scheltema et al., 2003); so far not tallied is the number of genera without copulatory spicules; and sclerites can be of such a common sort that they often cannot be used with certainty for identifications, e.g., many Cavibelonia species, although there are no thoroughly analyzed scleritomes among Cavibelonia. Inadequate material requires sectioning; quoting Hubrecht (1881, p. 30) in his seminal paper on Proneonemia sluiteri: "As to the exact shape of the radula [polystichous] I hold it to be preferable to postpone a definite judgment till it has been possible to prepare one out of a freshly caught animal ... [so] I felt no liberty to dispose of my two specimens in any other way than by making series of sections that could be indefinitely preserved." He must have felt the same way about his two specimens of $D$. festiva.

If there are few specimens or only one (some $14 \%$ of Solenogastres genera are monotypic, some represented with only a holotype, and many species are described from a single specimen, often a juvenile) there is a large chance that descriptions based only on internal anatomy and an inadequately examined scleritome may not hold for all future collections of related or conspecific specimens. Body expansion and contraction can be misleading in characterizing the positional relationship of organs. Further, if the only specimen is a juvenile, the undeveloped or only partially developed reproductive system may not be diagnostic. Recently collected material is usually well fixed, but poor preservation can be a problem (e.g., the anterior end of $L$. carinata herein). If there are only a few specimens, they do not provide the amount of variability actually present in a species.

Although it is surprising that Dondersiidae was recovered monophyletic in only one of the most parsimonious trees (not figured), only 21 of the 36 characters were parsimonyinformative. Notably, several characters in which all dondersiid species share the same state were not parsimonyinformative. Acanthomenia shares several characters with 
Table 1

Genera and species of Dondersiidae with depths and localities, listed by genus

\begin{tabular}{|c|c|c|c|c|}
\hline Genus & Species & Author and Date & Depth m & Locality \\
\hline Dondersia & annulata & Nierstrasz 1902 & 55 & Indonesia \\
\hline Dondersia? & cnidevorans & Salvini-Plawen 1978 & $659-714$ & Antarctica \\
\hline Dondersia & festiva & Hubrecht 1888 & $60-65$ & Mediterranean \\
\hline Dondersia & indica $^{1}$ & Stork 1941 & 55 & Indonesia \\
\hline Dondersia? & laminata & Salvini-Plawen 1978 & $311-426$ & Antarctica \\
\hline Dondersia & namibiensis & sp. nov. & $69-1007$ & Cape Basin \\
\hline Dondersia? & stylastericola & Salvini-Plawen 1978 & 300 & Antarctica \\
\hline Dondersia & incali & (Scheltema 1999) & 2091 & W European B \\
\hline Heathia $^{2}$ & porosa & (Heath 1911) & $900-1078$ & So. California \\
\hline Helluoherpia ${ }^{2}$ & aegiri & Handl \& Büchinger 1996 & $185-250$ & Norway \\
\hline Ichthyomenia ${ }^{2}$ & ichthyodes & (Pruvot 1890$)$ & 80 & Mediterranean \\
\hline Lyratoherpia & californica & (Heath 1911) & $38-43$ & So. California \\
\hline Lyratoherpia? & bracteata & Salvini-Plawen 1978 & $148-201$ & Antarctica \\
\hline Lyratoherpia & carinata & Salvini-Plawen 1978 & $344-714$ & Antarctica \\
\hline Micromenia & fodiens & (Schwabl 1955) & 40 & Gulmarfjord \\
\hline Micromenia & simplex & Leloup 1948 & 48 & Barents Sea \\
\hline Micromenia & subrubra & Salvini-Plawen 2003a & $120-140$ & Mediterranean \\
\hline Nematomenia & arctica & Thiele 1913a & $?$ & Spitzbergen \\
\hline Nematomenia & banyulensis & (Pruvot 1890) & $45-300$ & Norway, Medit. \\
\hline Nematomenia & corallophila & (Kowalevsky 1881, cited in Thiel, 1913c)) & 30 & Mediterranean \\
\hline Nematomenia & flavens & (Pruvot 1890) & $45-90$ & Mediterranean \\
\hline Nematomenia & glacialis & Thiele $1913 \mathrm{~b}$ & 385 & Antarctica \\
\hline Nematomenia & incirrata & Salvini-Plawen 1978 & $298-302$ & Antarctica \\
\hline Nematomenia & norvegica $^{3}$ & Odhner 1921 & $150-200$ & Norway \\
\hline Nematomenia & platypoda & (Heath 1911) & 868 & Agulhas Bank \\
\hline Nematomenia & protecta & Thiele $1913 \mathrm{~b}$ & 385 & Antarctica \\
\hline Nematomenia & pytalosa & Salvini-Plawen 1978 & $135-201$ & Terra d. Fuego \\
\hline Nematomenia & squamosa & Thiele $1913 \mathrm{~b}$ & 385 & Antarctica \\
\hline Nematomenia & tegulata & Salvini-Plawen 1978 & $135-494$ & Terra d. Fuego \\
\hline Squamatoherpia ${ }^{2}$ & tricuspidata & Büchinger \& Handl 1996 & to 250 & Norway \\
\hline Stylomenia & salvatori & Pruvot 1899 & $?$ & Banyuls, Medit. \\
\hline Stylomenia & sulcodoryata & Handl \& S.-Plawen 2001 & 185 & Norway \\
\hline
\end{tabular}

Dondersiidae and a close relationship cannot be ruled out at present, although placement of Acanthomenia within Dondersiidae is admittedly unlikely.

The list of characters in Table 2 for Dondersia and Lyratoherpia species (and outgroups) considered here should be informative in untangling relationships among other dondersiid species and genera. In an expanded form, it could serve as the basis for a cladistic analysis of Solenogastres ( $c f$. Salvini-Plawen, 2003b). The use of morphological characters in phylogenetic investigations of Solenogastres is particularly important because, like other small deepsea taxa, aplacophorans are commonly bulk-fixed in formalin and thus molecular phylogenetic investigations in this group are challenging. However, a newly described technique for extracting DNA from formalin-fixed material offers new opportunities for molecular phylogenies of Aplacophora (Schander and Halanych, 2003; Skage and Schander, 2007). Additionally, deep-sea researchers are be- ginning to employ ethanol and other nucleic acid-preservation methods in their standard bulk fixation protocols (e.g., BioSkag and IceAGE research expeditions), and molecular investigations employing material from these expeditions are under way (e.g., Kocot et al., unpubl. data; Mikkelsen et al., University Museum of Bergen, Norway; unpubl. data).

\section{Acknowledgments}

AHS and KMK mourn the loss of Christoffer Schander, too early in his life; KMK has provided the cladistic analysis Chris was working on at his death, and has further edited the entire manuscript with care.

Previous to the cladistic analysis, Dr. Luitfried v. SalviniPlawen thoroughly critiqued and added to the manuscript, and graciously granted us permission to include his images and reconstruction of the Dondersia incali reproductive system (Figs. 23, 25-28), despite not agreeing with all our 
Table 2

Data matrix for cladistic morphological analysis

\begin{tabular}{|c|c|c|c|c|c|c|c|c|}
\hline Character & $\begin{array}{l}\text { Dondersia } \\
\text { festiva }\end{array}$ & $\begin{array}{l}\text { Dondersic } \\
\text { incali } \\
\end{array}$ & $\begin{array}{l}\text { a Dondersia } \\
\text { namibiensis }\end{array}$ & $\begin{array}{l}\text { Lyratoherpia } \\
\text { carinata }\end{array}$ & $\begin{array}{l}\text { a Lyratoherpia } \\
\text { californica }\end{array}$ & $\begin{array}{c}\text { Tegulaherpia } \\
\text { tasmanica }\end{array}$ & $\begin{array}{l}\text { Acanthomenia } \\
\text { arcuata }\end{array}$ & Character Coding \\
\hline 1 Body length & 2 & 1 & 1 & 3 & 2 & 1 & 2 & $\begin{array}{l}\text { (1) } 1-5 \mathrm{~mm} \text {; (2) } 6-10 \mathrm{~mm} \text {; } \\
\text { (3) }>10 \mathrm{~mm}\end{array}$ \\
\hline 2 Anterior to midbody height & 1 & 1 & 1 & 1 & 1 & 1 & 2 & (1) Greater than; (2) Same as \\
\hline $\begin{array}{l}3 \text { Posterior to midbody } \\
\text { height }\end{array}$ & 2 & 1 & 1 & 3 & 3 & 3 & 3 & $\begin{array}{l}\text { (1) Greater than; (2) Same as; } \\
\text { (3) Less than }\end{array}$ \\
\hline 4 Carina & 2 & 2 & 2 & 1 & 1 & 2 & 2 & (1) Present; (2) Absent \\
\hline 5 Shape of anterior end & 2 & 2 & 2 & 1 & 1 & 2 & 1 & (1) Rounded; (2) Rostrate \\
\hline 6 Shape of posterior end & 3 & 3 & 3 & 1 & 1 & 2 & 2 & $\begin{array}{l}\text { (1) Rounded; (2) Tapered; } \\
\text { (3) Dorsal "finger" }\end{array}$ \\
\hline 7 Posteroventral lobe & 1 & 1 & 1 & 1 & 1 & 2 & 2 & (1) Present; (2) Absent \\
\hline $\begin{array}{l}8 \text { Greatest anterior height to } \\
\text { width }\end{array}$ & 2 & 2 & 2 & 1 & 1 & 2 & $?$ & (1) Same; (2) Width < height \\
\hline 9 Posterior width to height & 3 & 1 & 1 & 1 & 1 & 2 & $?$ & $\begin{array}{l}\text { (1) Same; (2) Width }<\text { height; } \\
\text { (3); Width }>\text { height }\end{array}$ \\
\hline 10Pedal pit & 1 & 2 & 2 & 1 & 1 & 1 & 2 & (1) Distinct; (2) Indistinct \\
\hline 11 Scleritome & 2 & 2 & 2 & 2 & 2 & 1 & 3 & $\begin{array}{l}\text { (1) Smooth; (2) Rough; } \\
\text { (3) Spiny }\end{array}$ \\
\hline 12Scleritome evenness & 2 & 2 & 2 & 1 & $?$ & 1 & 1 & $\begin{array}{l}\text { (1) Even anterior to posterior; } \\
\text { (2) Sclerites larger posteriorly }\end{array}$ \\
\hline 13 Number of sclerite types ${ }^{1}$ & 1 & 2 & 2 & 1 & $?$ & 2 & 3 & (1) 3 ; (2) 4; (3) More than 4 \\
\hline 14 Solid scales with rims & 1 & 1 & 1 & 2 & $?$ & 3 & 2 & $\begin{array}{l}\text { (1) Both with and without stem; } \\
\text { (2) Without stem; (3) Absent }\end{array}$ \\
\hline 15 Solid rods & 1 & 1 & 1 & 2 & $?$ & 3 & 3 & $\begin{array}{l}\text { (1) Present, ends rounded; } \\
\text { (2) Present, distally pointed; } \\
\text { (3) Absent }\end{array}$ \\
\hline 16Other solid sclerite types & 2 & 2 & 2 & 2 & $?$ & 2 & 1 & (1) Present; (2) Absent \\
\hline 17Hollow spines & 2 & 2 & 2 & 2 & $?$ & 2 & 1 & (1) Present; (2) Absent \\
\hline 18 Number of rows in radula & 1 & 1 & 1 & 1 & $?$ & 2 & 1 & (1) $5-10$; (2) $>10$ \\
\hline 19Tooth type & 2 & 2 & 2 & 2 & 2 & 1 & 2 & $\begin{array}{l}\text { (1) Upright hooks; (2) Denticles } \\
\text { on plates }\end{array}$ \\
\hline $\begin{array}{l}\text { 20 Number of teeth per } \\
\text { row }\end{array}$ & 1 & 1 & 1 & 1 & 1 & 2 & 1 & (1) Monostichous; (2) Distichous \\
\hline 21 Denticle fusion & 2 & 2 & 2 & 2 & 2 & 1 & 3 & $\begin{array}{l}\text { (1) Absent; (2) Present, medial; } \\
\text { (3) Present, lateral }\end{array}$ \\
\hline 22 Copulatory spicule sac & 2 & 2 & 2 & 3 & $?$ & 1 & 4 & $\begin{array}{l}\text { (1) Paired; (2) Single; (3) Single } \\
\text { then paired; (4) Absent }\end{array}$ \\
\hline 23 Number of spicules per sac & 1 & 1 & 1 & 2 & $?$ & 2 & 3 & (1) $1 ;(2) ; 2 ;(3) ;$ Absent \\
\hline 24 Accessory spicules in sac & 1 & 1 & 1 & 2 & $?$ & 2 & 2 & (1) Present; (2) Absent \\
\hline $\begin{array}{l}25 \text { Accessory ("abdominal") } \\
\text { spicules, mantle } \\
\text { epidermis }\end{array}$ & 2 & 2 & 2 & 2 & $?$ & 2 & 1 & (1) Present; (2) Absent \\
\hline $\begin{array}{l}\text { 26Ventrolateral foregut gland } \\
\text { cell lobes }\end{array}$ & 2 & 2 & 2 & 2 & 2 & $?$ & 1 & (1) Muscular; (2) Non-muscular \\
\hline $\begin{array}{l}\text { 27Ventrolateral foregut gland } \\
\text { cell necks }\end{array}$ & 2 & 2 & 2 & 2 & 2 & 3 & 1 & $\begin{array}{l}\text { (1) Long, muscular; (2) Long, } \\
\text { non-muscular; (3) short } \\
\text { ("follicles"in literature) }\end{array}$ \\
\hline 28Fusion of ducts & 1 & 1 & 1 & 2 & 2 & 2 & 1 & (1) Present; (2) Absent \\
\hline 29Pedal pit glandular lobes & 1 & 1 & 1 & 2 & 2 & $?$ & $?$ & $\begin{array}{l}\text { (1) }<1 / 2 \text { distance dorsally; } \\
\text { (2) }>1 / 2 \text { distance dorsally }\end{array}$ \\
\hline 30Mesenchyme & 2 & 2 & 2 & 1 & 1 & 1 & $?$ & (1) Filling hemocoel; (2) slight \\
\hline $\begin{array}{l}31 \text { Anterior dorsal midgut } \\
\text { caecum }\end{array}$ & 1 & 1 & 1 & 1 & 1 & 2 & $?$ & (1) Present; (2) Absent \\
\hline $\begin{array}{l}\text { 32 Ventral longitudinal } \\
\text { muscles }\end{array}$ & 2 & 2 & 2 & 2 & 2 & 2 & 1 & (1) Present; (2) Weak/absent \\
\hline 33 Midgut & 1 & 2 & 2 & 1 & 1 & 2 & 2 & $\begin{array}{l}\text { (1) Sacculate; (2) Weakly/not } \\
\text { sacculate }\end{array}$ \\
\hline
\end{tabular}


Table 2 (Continued)

\begin{tabular}{|c|c|c|c|c|c|c|c|c|}
\hline Character & $\begin{array}{c}\text { Dondersia } \\
\text { festiva }\end{array}$ & $\begin{array}{c}\text { Dondersia } \\
\text { incali }\end{array}$ & $\begin{array}{l}\text { Dondersia } \\
\text { namibiensis }\end{array}$ & $\begin{array}{c}\text { Lyratoherpic } \\
\text { carinata }\end{array}$ & $\begin{array}{c}\text { Lyratoherpia } \\
\text { californica }\end{array}$ & $\begin{array}{c}\text { Tegulaherpic } \\
\text { tasmanica }\end{array}$ & $\begin{array}{l}\text { anthomenia } \\
\text { arcuata }\end{array}$ & Character Coding \\
\hline 34Posteroventral lobe & 1 & 1 & 1 & 2 & $?$ & 3 & 3 & $\begin{array}{l}\text { (1) Present with copulatory } \\
\text { spicules; (2) Present without } \\
\text { copulatory } \\
\text { spicules; (3) Absent }\end{array}$ \\
\hline 35 Paired seminal vesicles & 3 & 3 & 3 & 3 & $?$ & 1 & $?$ & $\begin{array}{l}\text { (1) Pocket off gonopericardial } \\
\text { ducts; (2) Single lobe off } \\
\text { upper } \\
\text { gametoduct; }(3)>1 \text { lobe off } \\
\text { uppergametoduct }\end{array}$ \\
\hline 36Paired seminal recepticles & 1 & 2 & 2 & 1 & 1 & 2 & 2 & (1) Present; (2) Absent \\
\hline
\end{tabular}

${ }^{1}$ Excluding those beside the pedal groove.

interpretations of morphology and taxonomic placement. The assessment of $D$. incali took place between Dr. SalviniPlawen and AHS at the $2^{\text {nd }}$ international aplacophoran workshop in Ferrol, Spain. We thank Jeroen Goud at the National Museum of Natural History, Leiden, for the loan of type material, for comments on types, and for copies of the Nierstrasz catalogue for $D$. festiva. The loan of types from the National Museum of Natural History-Smithsonian Institution and California Academy of Science is gratefully acknowledged. Michiel Vos and Rudolf Scheltema translated parts of Hubrecht's 1888 paper. Alan Kuzirian helped us with the SEMs in Figures 33 and 34. Carl Otto Schander rendered the drawing in Figure 1 from De Groot's original in Hubrecht (1888). Major funding was by a U. S. National Science Foundation grant (DEB-9521930) under the PEET program (Partnerships for Enhancing Expertise in Taxonomy). This is Auburn University Marine Biology contribution number 88 and Molette Laboratory contribution number 7 .

\section{Literature Cited}

Büchinger, T., and C. Handl. 1996. Squamatoherpia tricuspidata gen. n. et. sp. n. aus der Nordsee. Ann. Naturhist. Mus. Wien 98B: 57-63.

García-Álvarez, O., and L. v. Salvini-Plawen. 2007. Species and diagnosis of the families and genera of Solenogastres (Mollusca). Iberus 25: 73-143.

Gil-Mansilla, E., O. García-Álvarez, and V. Urgorri. 2008. New Acanthomeniidae (Solenogastres, Cavibelonia) from the abyssal Angola Basin. Zootaxa 1866: 175-186.

Giribet, G., A. Okusu, A. R. Lindgren, S. W. Huff, M. Schrödl, and M. K. Nishiguchi. 2006. Evidence for a clade composed of molluscs with serially repeated structures: Monoplacophorans are related to chitons. Proc. Natl. Acad. Sci. USA 103: 7723-7728.

Glaubrecht, M., L. Maitas, and L. v. Salvini-Plawen. 2005. Aplacophoran Mollusca in the Natural History Museum Berlin. An annotated catalogue of Thiele's type specimens, with a brief review of "Aplacophora" classification. Zoosyst. Evol. Mitt. Mus. Naturk. Berlin 81: $145-166$.

Handl, C., and T. Büchinger. 1996. Helluoherpia aegiri gen. n. et sp. n. aus Norwegen. Ann. Nathist. Mus. Wien 98B: 65-70.

Handl, C., and L. v. Salvini-Plawen. 2001. New records of Soleno-
gastres-Pholidoskepia (Mollusca) from Norwegian fjords and shelf waters including two new species. Sarsia 86: 367-381.

Handl, C., and L. v. Salvini-Plawen. 2002. New records of Solenogastres-Cavibelonia (Mollusca) from Norwegian fjords and shelf waters including three new species. Sarsia 87: 423-450.

Handl, C. H., and C. Todt. 2005. Foregut glands of Solenogastres (Mollusca): anatomy and revised terminology. J. Morphol. 265: $28-$ 42.

Haszprunar, G. 2000. Is the Aplacophora monophyletic? A cladistic point of view. Am. Malacol. Bull. 15: 115-130.

Heath, H. 1911. Reports on the scientific results of the expedition to the tropical Pacific, in charge of Alexander Agassiz, by the U. S. Fish Commission Steamer "Albatross," from August, 1899, to June, 1900, Commander Jefferson Moser, U. S. N., commanding. XIV. The Solenogastres. Mem. Mus. Comp. Zool. 45 (1): 9-180, 40 pls.

Hoffman, S. 1949. Studien über das Integument der Solenogastren nebst Bemerkungen über die Verwandtschaft zwischen den Solenogastren und Placophoren. Zool. Bidr. Upps. 27: 293-427.

Hubrecht, A. A. W. 1881. Proneomenia sluiteri gen. et sp. n., with remarks upon the anatomy and histology of the Amphineura. Niederländische Archiv für Zoologie 1881, Suppl. 9, 75 pp., pl. 1-4.

Hubrecht, A. A. W. 1888. Dondersia festiva gen. et spec. nov. Pp. 324-339, pl. 8-9 in Donders Feestbundel. Nederl. Tijdschr. Geneesk. Amsterdam.

Kocot, K. M., J. T. Cannon, C. Todt, M. R. Citarella, A. B. Kohn, A. Meyer, S. R. Santos, C. Schander, L. L. Moroz, B. Lieb, and K. M. Halanych. 2011. Phylogenomics reveals deep molluscan relationships. Nature 477: 452-456.

Kowalevsky, A. 1881. Neomenia corallophila; Coeloplana metschnikovi. Izvestia Obschchestvo Liubitelei Estestvoznaniia Anthropologii Ethnografi, Moscow 43(1): 5 pp., fig. 1-15. [Soc. amis sci. natur., d'anthropol., et d'ethnogr.]. (Cited in Thiele, 1913c, p. 17).

Leloup, E. 1948. Un nouveau Solenogastre à peau nue de l'Océan Glacial Arctique. Micromenia simplex g. nov. sp. nov. Bull. Mus. R. Hist. Nat. Belgique 24(19): 1-7.

Lovén, S. 1844. Chaetoderma n. g., ett nytt maskslagte. Öfvers. Kongl. Vetens.-Akad. Förhandl. 1844 1(4): 116, pl. 2.

Nielsen, C., G. Haszprunar, B. Ruthensteiner, and A. Wanninger. 2007. Early development of the aplacophoran mollusc Chaetoderma. Acta Zool. 88: 231-247.

Nierstrasz, H. F. 1902. The Solenogastres of the Siboga-Expedition. Siboga-Expéditie Monograph 47. E. J. Brill, Leiden.

Nierstrasz, H. F. 1905. Kruppomenia minima und die Radula der Solenogastren. Zool. Jahrb. Abt. Anat. Ont. Tiere 21: 655-702, p1. $39-41$. 
Nierstrasz, H. F., and H. A. Stork. 1940. Monographie der Solenogastren des Golfes von Neapel. Zoologica (Stuttg.) 99: 1-99.

Odhner, N. H. 1921. Norwegian Solenogastres. Bergens Museums Aarbok 1918-1919, Avhandlinger Og Arsberetning Universitet. Bergen, Naturvid. raekke $N r$. 3: 1-86.

Okusu, A. 2002. Embryogenesis and development of Epimenia babai (Mollusca Neomeniomorpha). Biol. Bull. 203: 87-103.

Passamaneck, Y. J., C. Schander, and K. M. Halanych. 2004. Investigation of molluscan phylogeny using large-subunit and small-subunit nuclear rRNA sequences. Mol. Phylogenet. Evol. 32: 25-38.

Ponder, W. F., and D. R. Lindberg. 2008. Phylogeny and Evolution of the Mollusca. University of California Press, Berkeley.

Pruvot, G. 1890. Sur quelques néoméniées nouvelles de la Méditerranée. Arch. Zool. Exp. Gén., Ser. 2 8: Notes et Revue, pp. xxi-xxiv.

Pruvot, G. 1891. L'organization de quelques Néoméniens des côtes de France. Arch. Zool. Exp. Gén., Ser. 2 9: 699-810.

Pruvot, G. 1899. Sur deux néoméniées nouveau de la Méditerranée. Arch. Zool. Exp. Gén., Ser. 3 7: 461-509.

Saito, H., and L. v. Salvini-Plawen. 2010. A new species of Anamenia (Mollusca: Solenogastres: Cavibelonia) from southern Japan. Venus 69: $1-15$.

Salvini-Plawen, L. v. 1978. Antarktische und subantarktische Solenogastres (eine Monographie: 1898-1974). Zoologica (Stuttg.) 128: $1-315$.

Salvini-Plawen, L. v. 2003a. Contributions to West-Mediterranean Solenogastres (Mollusca) with three new species. Iberus 21: 37-60.

Salvini-Plawen, L. v. 2003b. On the phylogenetic significance of the aplacophoran Mollusca. Iberus 21: 67-97.

Schander, C., and K. M. Halanych. 2003. DNA, PCR and formalized animal tissue-a short review and protocols. Org. Divers. Evol. 3: 195-205.

Scheltema, A. H. 1993. Aplacophora as progenetic aculiferans and the coelomate origin of mollusks as the sister taxon of Sipuncula. Biol. Bull. 184: 57-78.

Scheltema, A. H. 1999. New eastern Atlantic neomenioid aplacophoran molluscs (Neomeniomorpha, Aplacophora). Ophelia 51: 1-28.

Scheltema, A. H., and C. Schander. 2000. Discrimination and phylogeny of solenogaster species through the morphology of hard parts (Mollusca, Aplacophora, Neomeniomorpha). Biol. Bull. 198: 121-151.

Scheltema, A. H., and C. Schander. 2006. Exoskeletons: tracing molluscan evolution. Venus 65: 19-26.

Scheltema, A. H., K. Kerth, and A. M. Kuzirian. 2003. Original molluscan radula: comparisons among Aplacophora, Polyplacophora,
Gastropoda, and the Cambrian fossil Wiwaxia corrugata. J. Morphol. 257: 219-245.

Schwabl, M. 1955. Rupertomenia fodiens nov. gen., nov. spec., eine neue Lepidomeniide von der Südwestküste Schwedens. Öst. Zool. Zeitschr. 6: $90-146$.

Sigwart, J. D., and M. D. Sutton. 2007. Deep molluscan phylogeny: synthesis of palaeontological and neontological data. Proc. R. Soc. B 274: $2413-2419$.

Simroth, H. 1893. Kritische Bemerkungen über die Systematik der Neomeniiden. Z. Wiss. Zool. 56: 310-327.

Skage, M., and C. Schander. 2007. DNA from formalin-fixed tissue: extraction or repair? That is the question. Mar. Biol. Res. 3: 289-295.

Smith, S. A., N. G. Wilson, F. E. Goetz, C. Feehery, S. C. S. Andrade, G. W. Rouse, G. Giribet, and C. W. Dunn. 2011. Resolving the evolutionary relationships of molluscs with phylogenomic tools. $\mathrm{Na}$ ture 480: 364-367.

Stork, H. A. 1941. Solenogastren der Siboga-Expedition. Siboga-Expéditie 47b: 45-70, 2 pls. E. J. Brill, Leiden.

Thiele, J. 1913a. Ein neuer Solenogaster von Spitzbergen. Sitzungs. Gesell. Fr. Berlin 1913 160-162, figs. 1, 2.

Thiele, J. 1913b. Antarktische Solenogastren. Deutsche Südpolar-Expedition 14, Zoologie 6(1): 35-65, pl. 4-8.

Thiele, J. 1913c. Mollusca. Solenogastres. Das Tierreich, Vol. 38. R. Friedlander and Son, Berlin.

Todt, C., and A. Wanninger. 2010. Of tests, trochs, shells, and spicules: development of the basal mollusk Wirenia argentea (Solenogastres) and its bearing on the evolution of trochozoan larval key features. Front. Zool. 7: 6.

Tullberg, T. 1875. Neomenia, a new genus of invertebrate animals. Bih Kongl. Svenska Vetensk.-Akad. Handl. 3(13): 12 pp., pl. 1-2.

van Berkel, K., A. van Helden, and L. Palm, eds. 2012. A History of Science in the Netherlands. [Online] Available: http://www.dwc. knaw.nl/wp-content/berkelbio/42.nierstrasz.pdf [2012, May 16].

van Lummel, L. E. E. 1930. Untersuchungen über einige Solenogastren. Z. Morphol. Okol. 18: 347-383.

Vinther, J., E. A. Sperling, D. E. G. Briggs, and K. J. Peterson. 2011. A molecular palaeogeological hypothesis for the origin of aplacophoran molluscs and their derivation from chiton-like ancestors. Proc. R. Soc. B 279: 1259-1268.

Wilson, N. G., G. W. Rouse, and G. Giribet. 2010. Assessing the molluscan hypothesis Serialia (Monoplacophora + Polyplacophora) using novel molecular data. Mol. Phylogenet. Evol. 54: 187-193. 


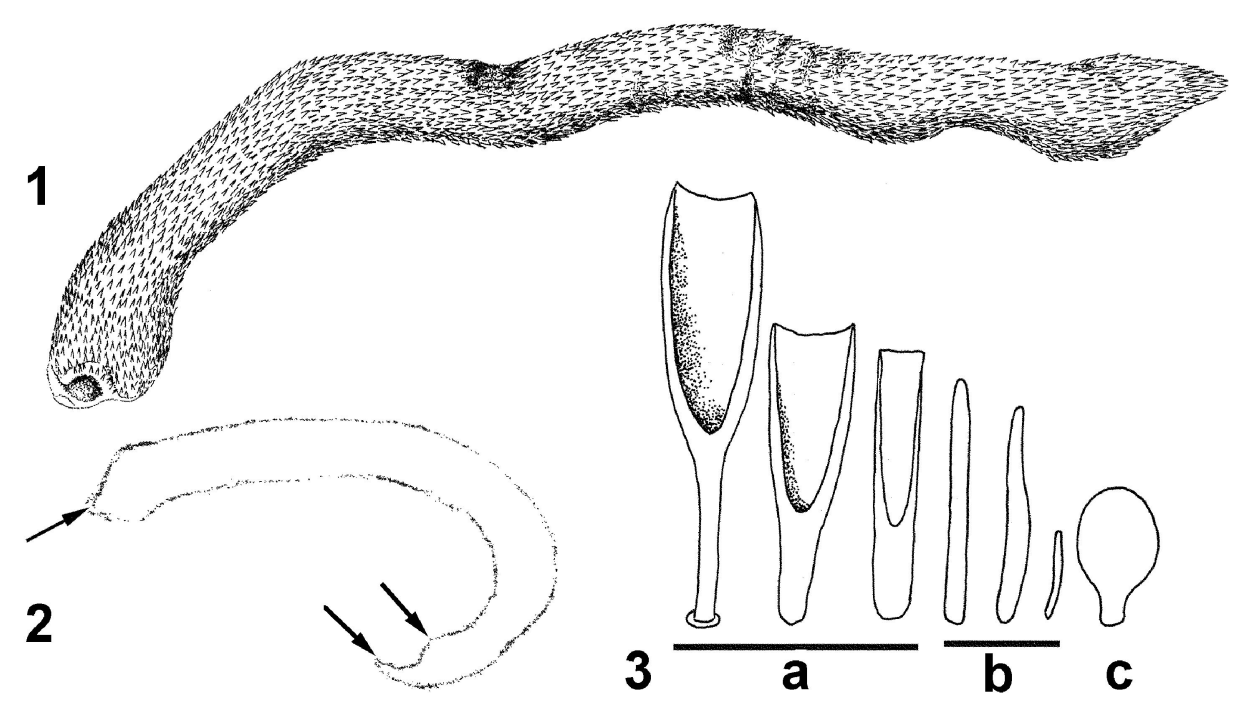

Figure 1-3. Dondersia festiva Hubrecht, 1888. (1) Holotype (length $\sim 10 \mathrm{~mm}$ ), NNM No. 75. (2) Nierstrasz's unretouched outline of NNM No. 74 before sectioning; showing beaked anterior end, posteroventral body lobe, and fingerlike posterior extension (arrows). (3) Sclerites redrawn from Hubrecht (1888): a, stemmed trowel-like; b, rods; c, stemmed ovate; largest sclerite about $0.05 \mathrm{~mm}$. (1, redrawn by C. O. Schander; 2, from "Catalogus der Solenogastres" of Nierstrasz in the National Museum of Natural History-Naturalis, Leiden.) 

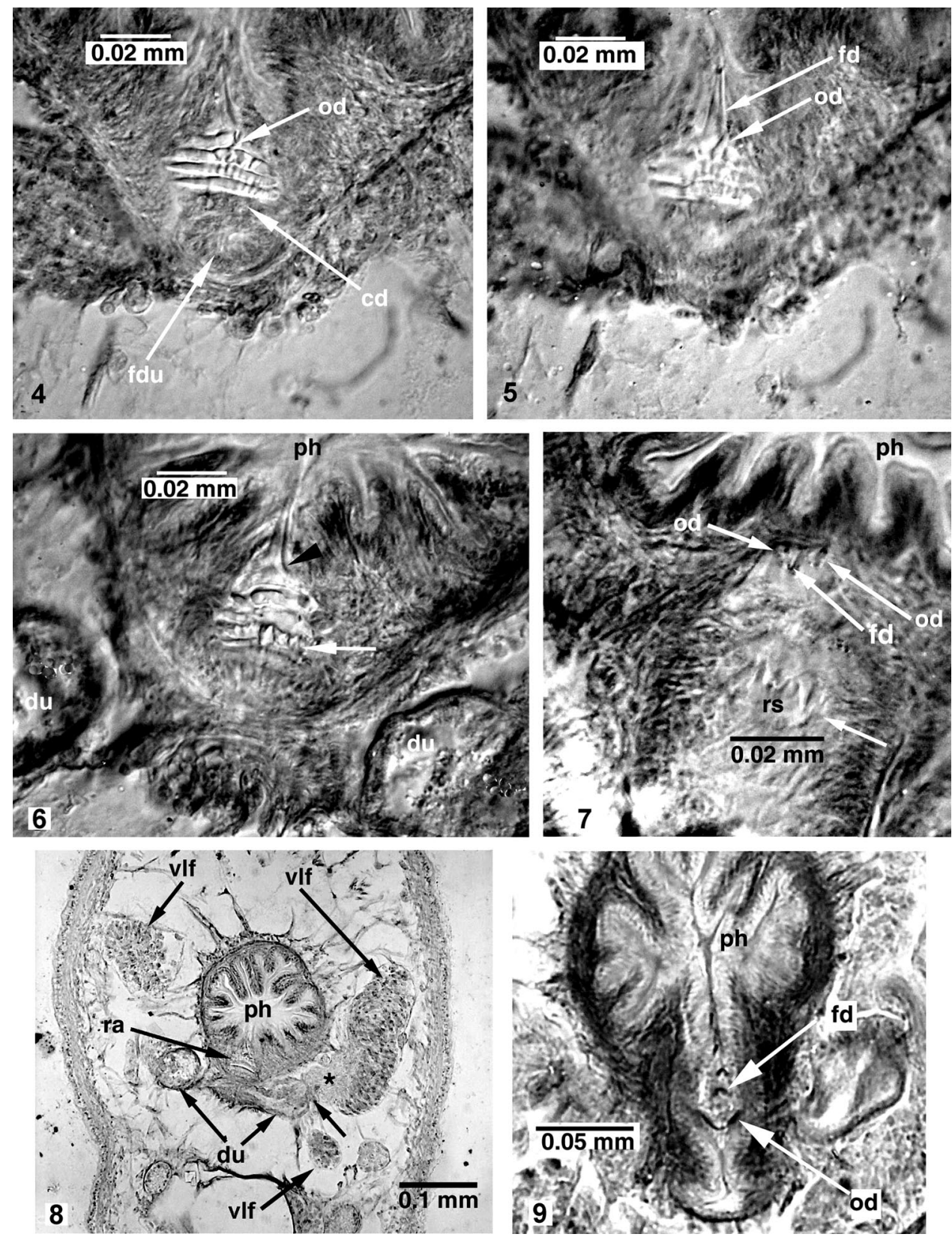

Figure 4-9. Dondersia festiva radula, ventrolateral foregut glands, and pharynx. (4-8) Holotype, NNM No. 75 (cf. Nierstrasz, 1905, figs 50-62; Nierstrasz and Stork, 1940, figs 25-34); (9) NNM specimen No. 74. (4) Base of right lateral denticle (od) swung from medial to upward and outward; fused ventrolateral foregut gland ducts (fdu); and a denticle-forming cell of radula sac (cd). (5) Same section as Fig. 4, different focus, showing same lateral outswung right denticle and narrow, fused medial denticles (fd) with longitudinal furrow marking line of fusion ( $c f$. Figs. 9, 10). (6) Denticle-like serrations of tooth base (white arrow), medial largest; proximal end of right medial tooth (black arrowhead) positioned downward from medial and to right at $90^{\circ}$ angle to outswung denticle in Fig. 5; and paired, muscular, aglandular ducts of ventrolateral foregut glands before they fuse (du); ph, pharynx. (7) Tooth cut at oblique angle, showing a major part of tooth base above serrations and with downward curving tips of fused medial (fd) and outswung lateral (od) denticles; unlettered arrow, downward curved tips of tooth forming in radula sac (rs) (cf. Figs. 11, 47-50, 52, 53). (8) One of several sections combined by Hubrecht into single figure (1888, fig. 10). Extraepithelial gland cells of ventrolateral foregut glands (vlf) dorsolateral and ventral to pharynx (ph), surrounded by thin membrane, entering short, muscular duct (unlettered arrow) by means of long, slender, unsheathed necks bundled together (asterisk); right duct (du) beginning to fuse with left duct beneath radula (ra) (fusion complete in Fig. 4). (9) Outswung denticles (od) and cross-sections of paired, medial, fused denticles (fd) with furrow between them. 


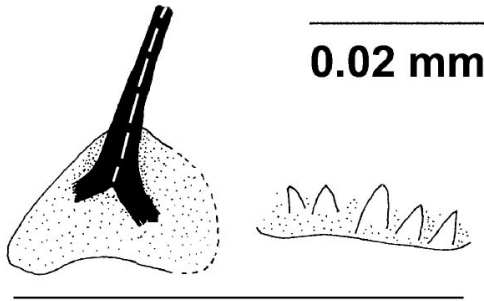

10

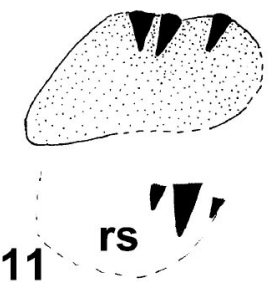

Figure 10-11. Dondersia festiva radula teeth, interpretive drawings of Figs. 6 and 7, respectively; denticles in black, base plate stippled; white dashed line, furrow of fused medial denticles. rs, radular sac. 

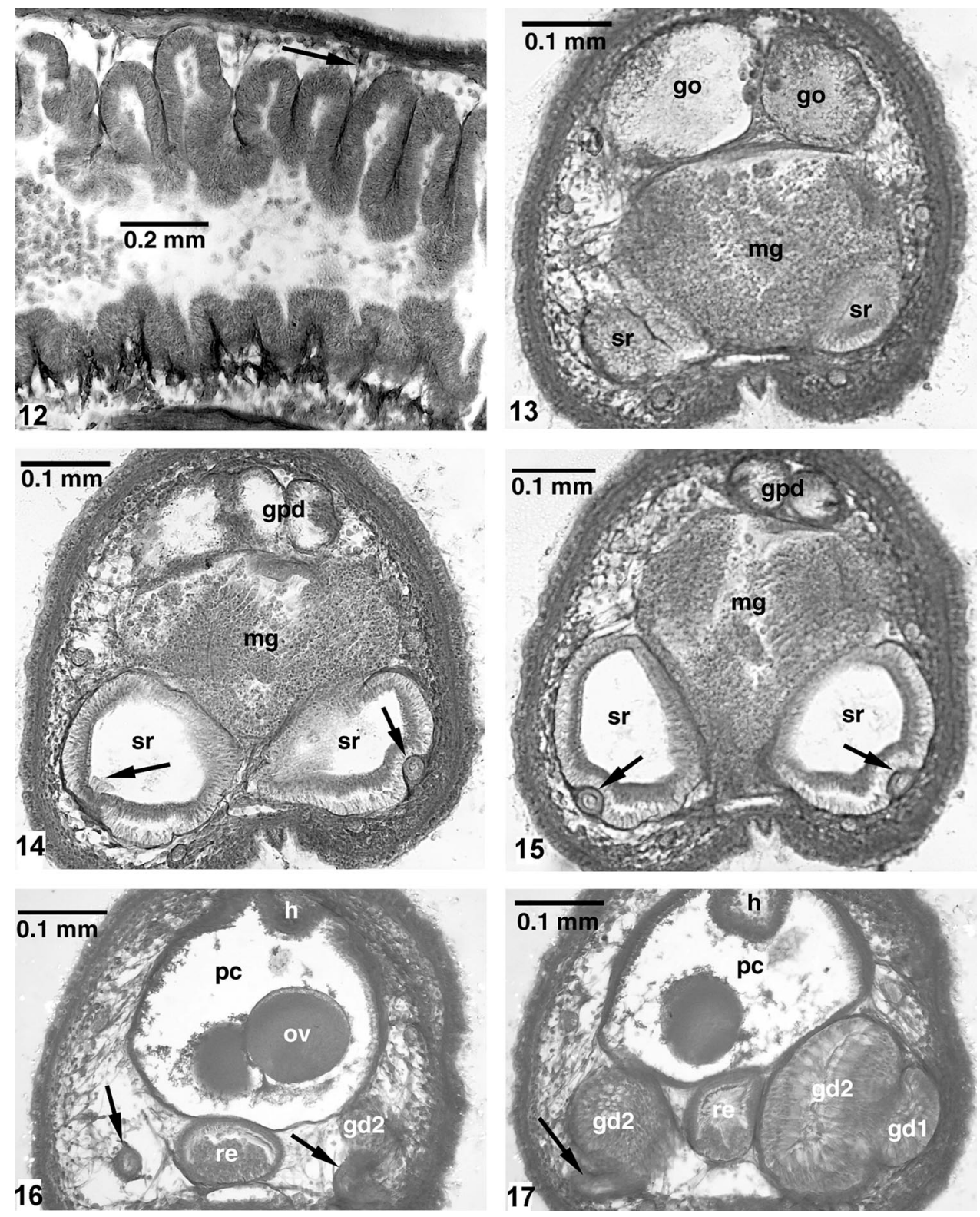

Figure 12-17. Dondersia festiva, holotype histologic sections. (12) Midsagittal section through midgut with sacculations caused by serial dorsolateral (= dorsoventral) muscle fibers (arrow). (13-17) Reproductive system, anterior to posterior (see Fig. 22). (13) Start of seminal receptacles beneath midgut. (14) Beginning of paired gonopericardial ducts; ciliated opening of seminal receptacle into its duct, left arrow; right arrow, seminal receptacle duct. (15) Seminal receptacles still beneath midgut; arrows, seminal receptacle ducts. (16) Pericardium with ovum, beginning of heart; beginning of rectum; seminal receptacle duct extending posteriorly beyond receptacle, left arrow; right arrow, receptacle duct joining start of lower gametoduct. (17) Seminal receptacle duct, lower gametoduct joined, left, arrow; on right, anterior end of upper gametoduct, lower gametoduct joined, opening just to left of letters gd1. gd1, upper gametoduct; gd2, lower gametoduct; go, gonad; gpd, gonopericardial ducts; h, heart; mg, midgut; ov, ovum; pc, pericardial cavity; re, rectum; sr, seminal receptacle. 

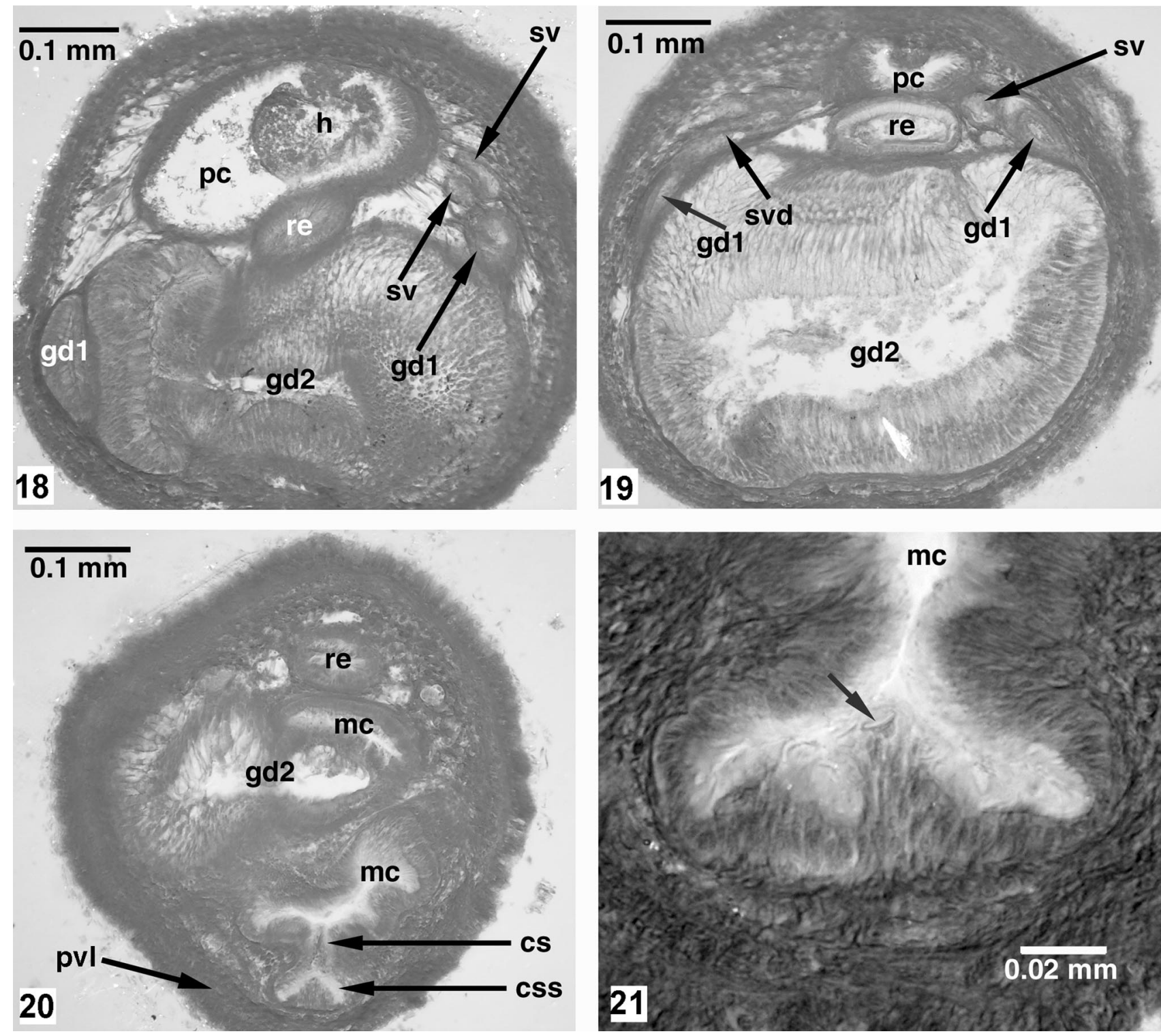

Figure 18-21. Dondersia festiva, holotype sections of posterior end (cont'd posteriorly from Fig. 17). (18) Paired lower gametoducts beginning to unite; two-lobed seminal vesicle on right are near union with upper gametoduct descending from narrowed pericardial cavity to lower gametoduct. (19) Lower gametoducts fused beneath rectum, filling more than half of body space; nearly vertical descent of upper gametoduct on left before joining lower gametoduct in Fig. 18, with probable duct of seminal vesicle emptying into it; pericardial cavity greatly reduced. (20) Bilobed, single copulatory spicule sac in posteroventral body lobe with channel connected to ventral wall of mantle cavity; lower gametoduct and rectum just before emptying into ventral mantle cavity, making with two mantle cavity pouches. (21) One of several shadows indicated by arrow, probably cuticular covering of paired proximal spicules within copulatory spicule sac at base of copulatory spicule, small size and shape indicating cross-sections ( $c f$. Figs. 41, 42, 54, 55). cs, channel for copulatory spicule; css, copulatory spicule sac; gd1, upper gametoduct; gd2, lower gametoduct; h, heart; mc, mantle cavity; pc, pericardial cavity; pvl, posteroventral lobe; re, rectum; sv, seminal vesicle; svd, duct of seminal vesicle. 

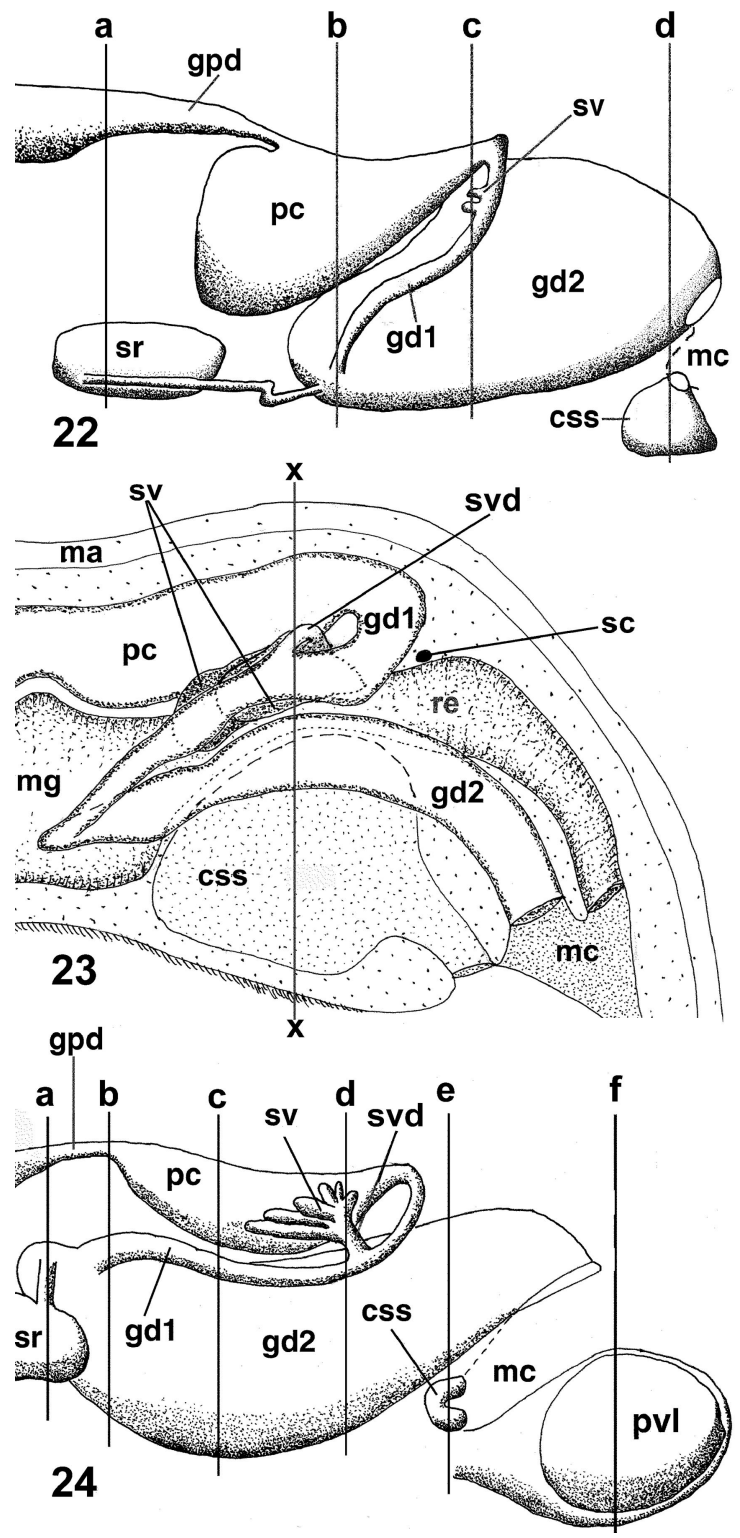

Figure 22-24. Semischematic reconstructions in sagittal section of dondersiid reproductive systems, left side, posterior to right. (22) Dondersia festiva from holotype, with large, united lower gametoducts; common duct of seminal vesicle lobes not drawn, lobes probably larger than drawn; lines a-d, locations of histologic sections in Figs. 14, 15 (a); 17 (b); 18, 19 (c); 20, 21 (d). (23) D. incali (paratype no. 2), one of paired seminal vesicles with two large lobes with common duct, lobes largely hidden by upper gametoduct; lower gameducts narrow; copulatory spicule sac enormous; line $\mathrm{x}-\mathrm{x}$, approximate location of histologic cross-sections in Figs. 25-28. (24) Lyratoherpia carinata Salvini-Plawen (paratype no. 3) with several lobes of seminal vesicles opening into single duct, voluminous lower gametoducts, very small, shallow copulatory spicule sac, and posteroventral body lobe entirely filled by mesenchyme; lines a-f, locations of histologic sections in Figs. 63 (a); 64 (b); 65 (c), 66-67 (d); 68-70 (e); 71 (f). css, copulatory spicule sac; gd1, upper gametoduct; gd2, lower gametoduct; gpd, gonopericardial duct; ma, mantle; mc, mantle cavity; mg, midgut; pc, pericardial cavity; pvl, mesenchyme-filled posteroventral body lobe; re, rectum; sc, suprarectal commissure; sr, seminal receptacle; sv, seminal vesicle lobes; svd, common duct of seminal vesicle lobes. (Fig. 23 kindly provided by Dr. Luitfried v. Salvini-Plawen, with permission.) 

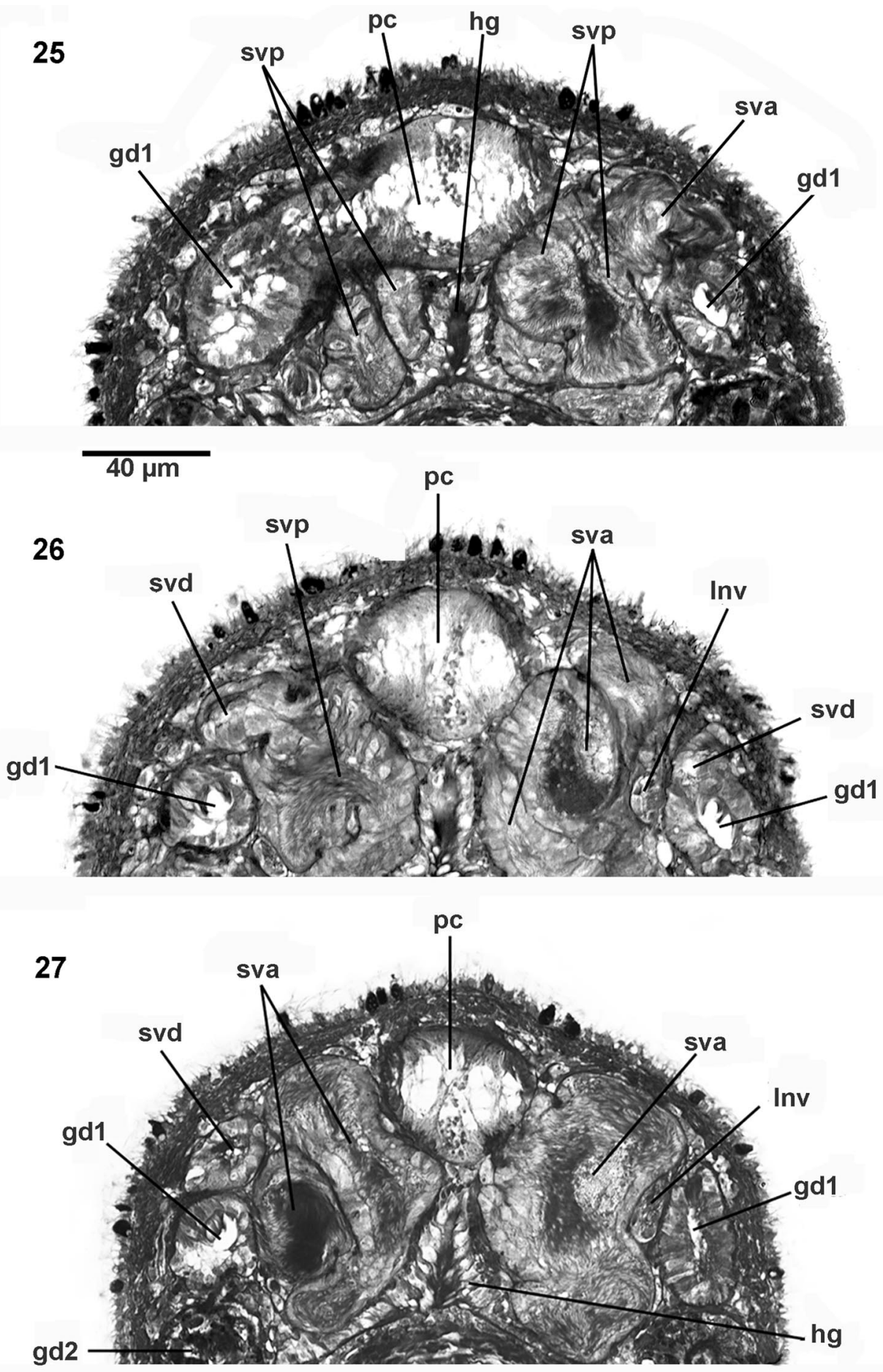

Figure 25-27. Dondersia incali (paratype no. 2), cross-sections through upper posterior body, from posterior to anterior. (25) Separation of upper gametoduct (gd1) from pericardium (pc, left), posterior lobes of seminal vesicles (left, right)(svp), and beginning of right anterior lobe (sva). (26) Left posterior and right anterior lobes of seminal vesicles; left posterior lobe entering common duct of lobes (svd), common duct of right lobes separated from lobes and about to enter upper gametoduct. (27) Right and left anterior seminal vesicle lobes; left, common duct separated from vesicle lobes and about to enter upper gametoduct. Other letters: gd2, lower gametoduct; hg, hindgut; lnv, lateral nerve cord. (Images kindly provided by Dr. Luitfried v. Salvini-Plawen, with permission.) 


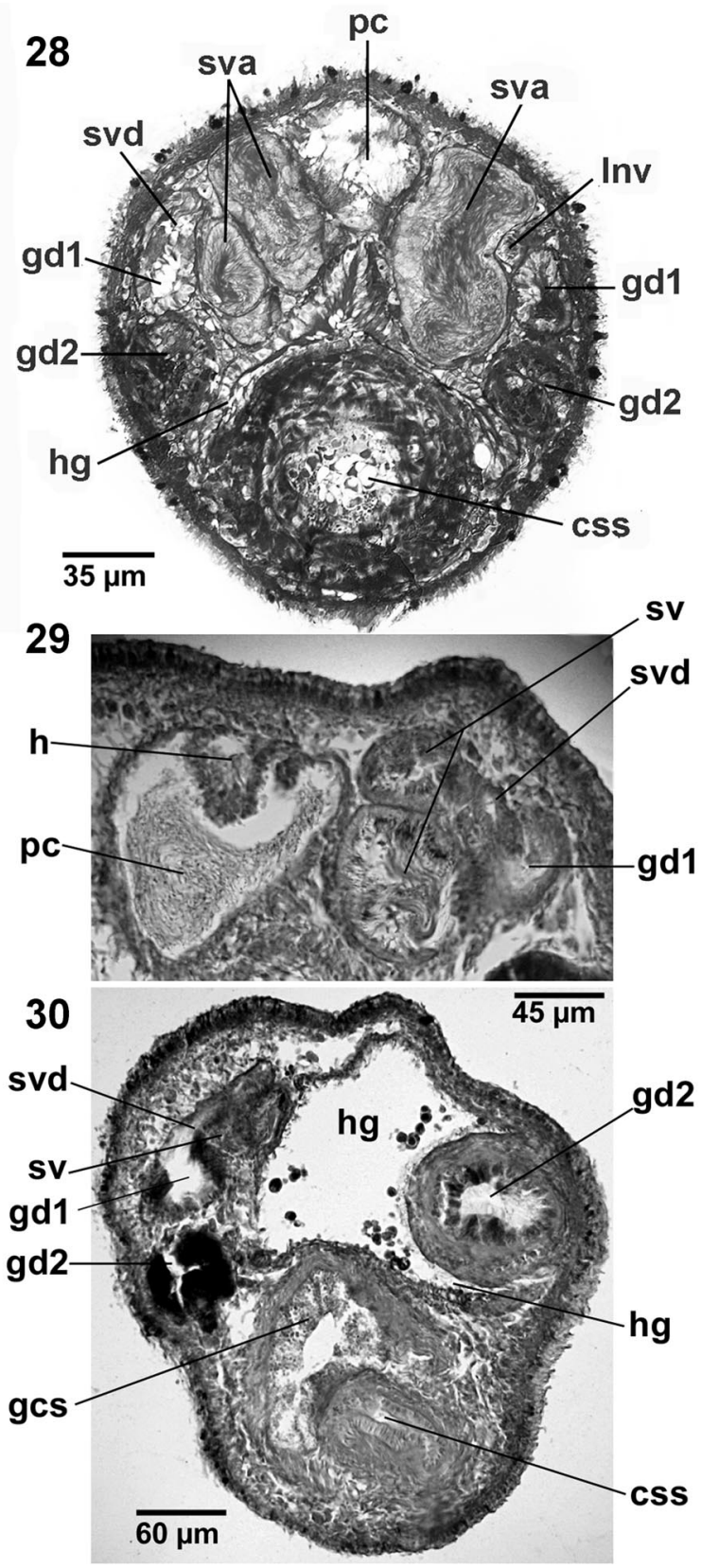

Figure 28-30. Dondersia incali and D. namibiensis. (28) D. incali, entire section anterior to Fig. 27 with left common duct (svd) of two seminal vesicle lobes entering upper gametoduct. (29) D. namibiensis, paratype A. Developing juvenile with two seminal vesicle lobes (sv) not yet distended beyond distinction by sperm, their common duct entering the upper gametoduct (gd1); eggs not ripe, only sperm in pericardium. (30) Same juvenile as Fig. 27, entire section posterior to most of seminal vesicle lobes, common duct of seminal vesicle lobes on left; copulatory apparatus already developed, although eggs and seminal vesicles not yet fully developed. Both Figs. 28 and 30 with narrow lower gametoducts (gd2) before fusion and voluminous copulatory spicule sac with large gland filling posteroventral body lobe. Other letters: css, copulatory spicule sac; gcs, copulatory spicule sac gland; h, heart; hg, hindgut; lnv, lateral nerve cord; pc, percardium; sva, anterior seminal vesicle lobes. (A, $2 \mu \mathrm{m}$ section, Richardson stained; B, C, $5 \mu \mathrm{m}$ sections, H \& E stained.)(Fig. 28 kindly provided by Dr. Luitfried v. Salvini-Plawen, with permission.) 


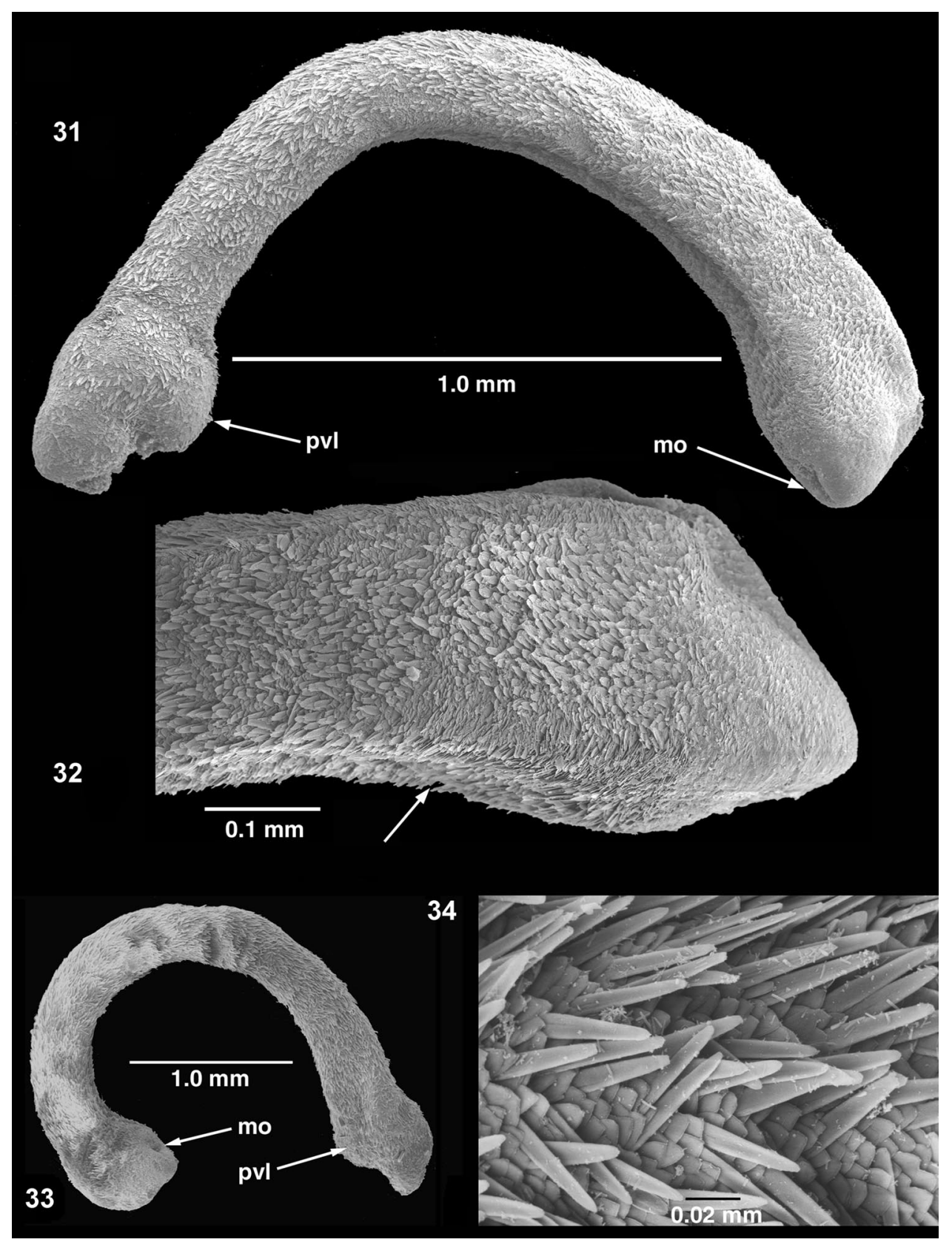

Figure 31-34. Dondersia namibiensis and D. incali, SEMs of paratypes. (31) D. namibiensis entire, anterior to right. (32) D. namibiensis anterior end; arrow, sclerites aligned along pedal groove. (33) D. incali, entire, anterior to left. (34) D. incali, scleritome. In both species, anteriormost end above mouth tapered, beaklike; height of anterior and posterior ends greater than midsection; and pronounced posteroventral lobe containing copulatory spicule sac and gland. Scleritomes (Figs. 32, 34) show rods of D. incali longer than in D. namibiensis. mo, mouth/vestibule opening; pvl, posteroventral body lobe. 


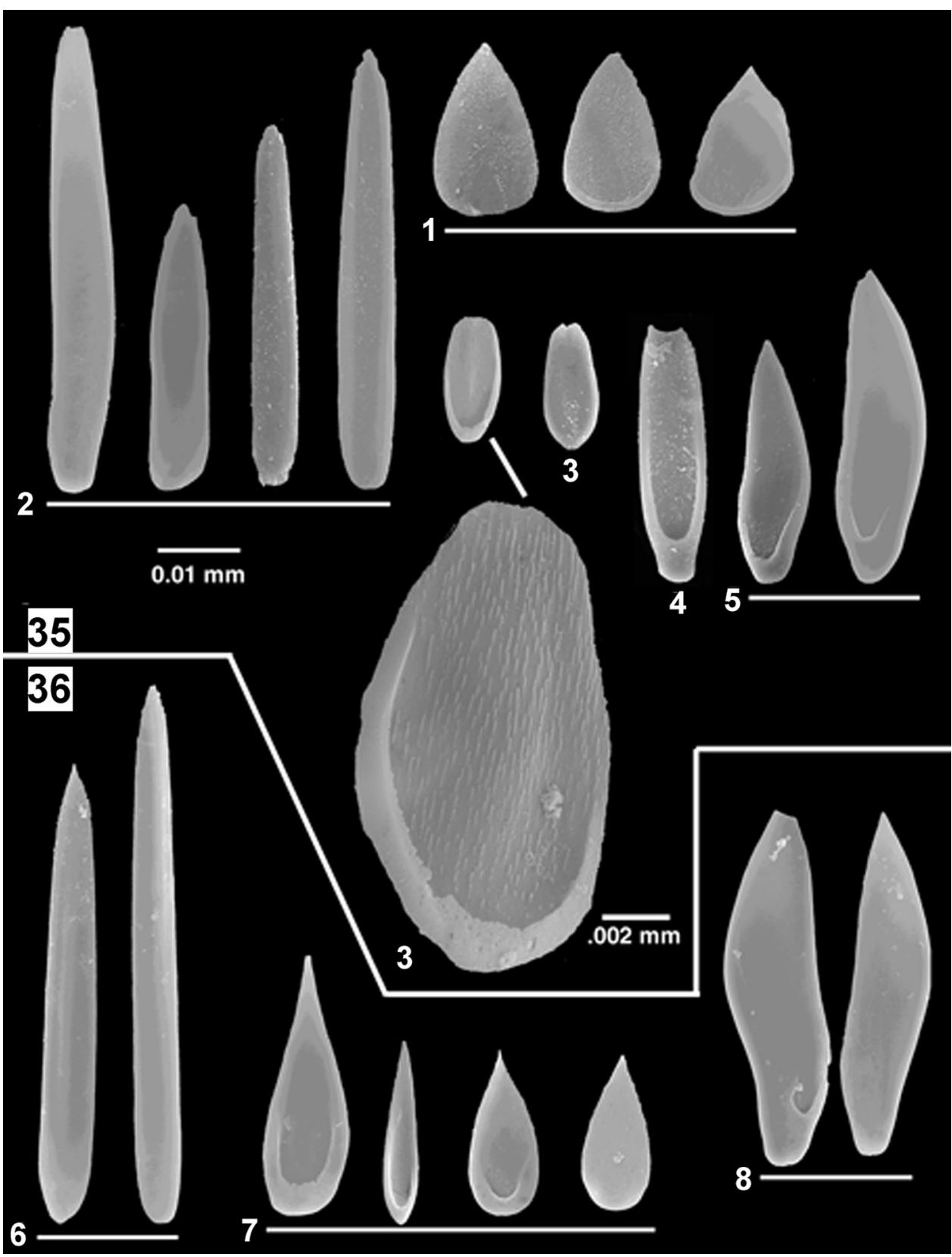

Figure 35-36. Sclerites (SEMs) of Dondersia namibiensis and D. incali. (35) D. namibiensis: 1, plectronshaped, narrowly, basally rimmed scales; 2 , rods; 3 , ovate narrowly rimmed scales; 4 , stemmed, troughed scale (cf. Fig. 3); 5, from beside foot groove. (36) $D$. incali: 6 , rods; 7, deeply basally rimmed scales, sharply pointed; 8 , from beside foot groove. 

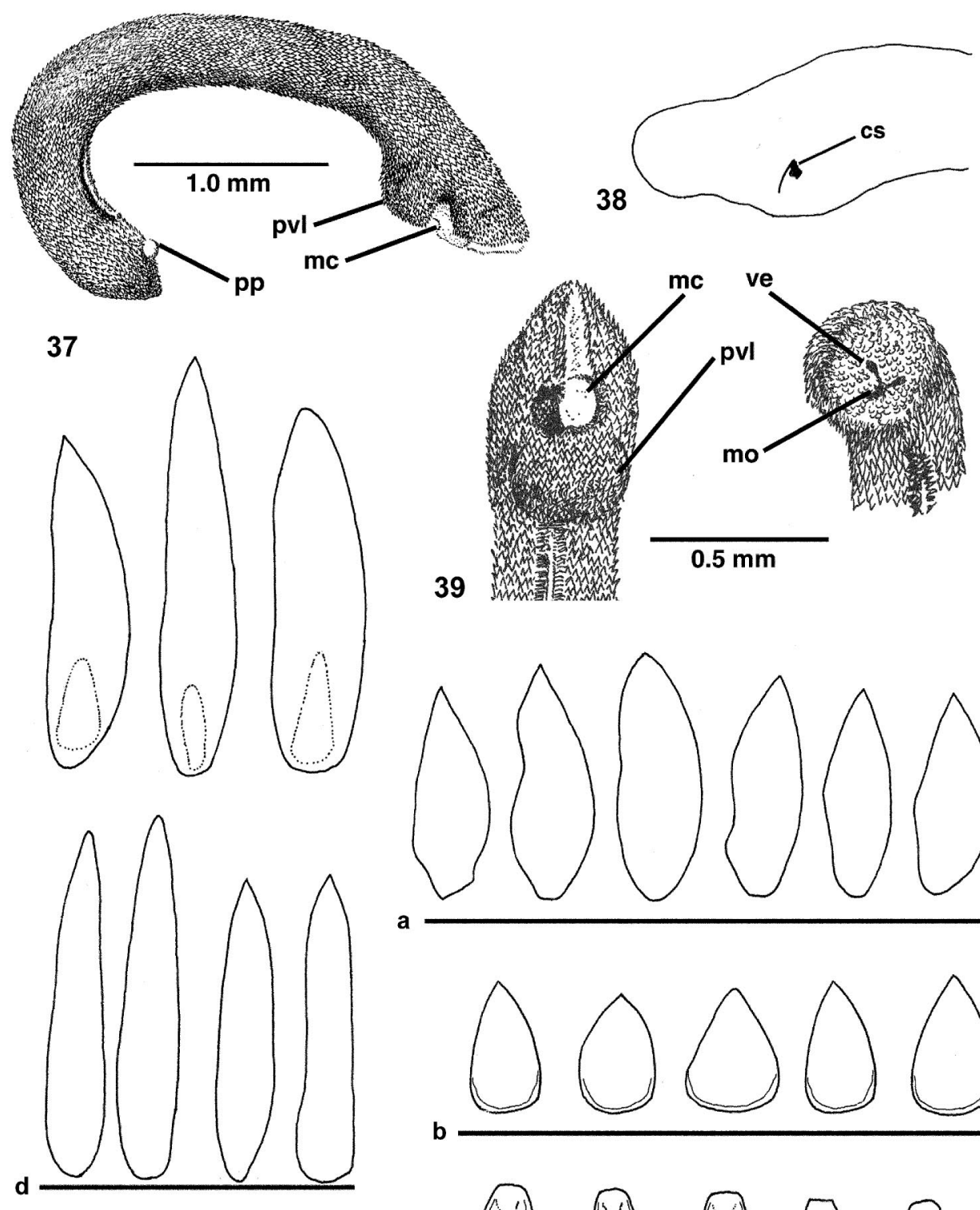

39
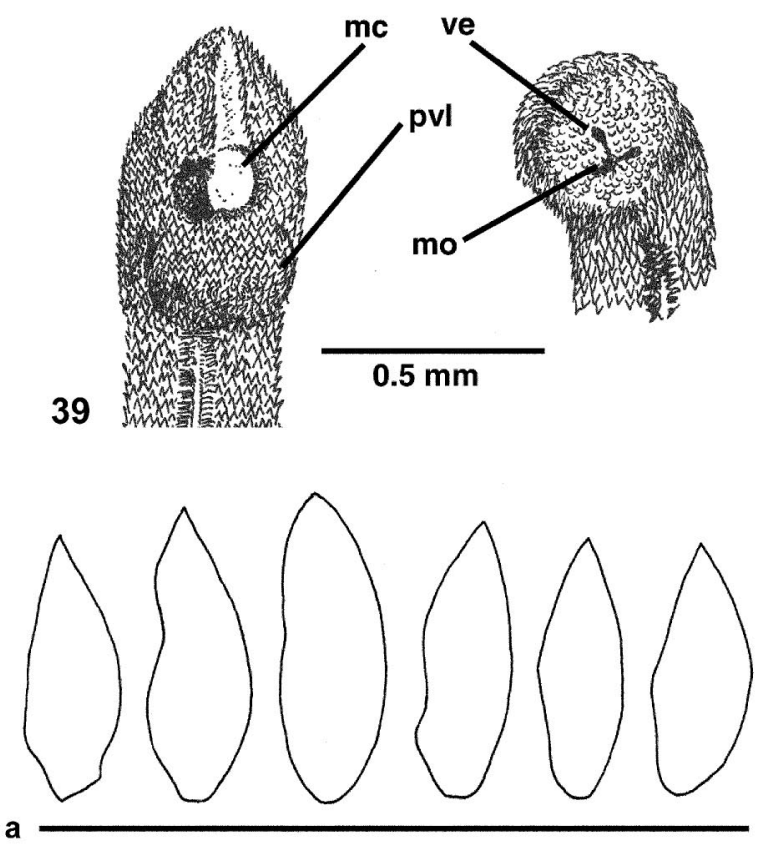

40
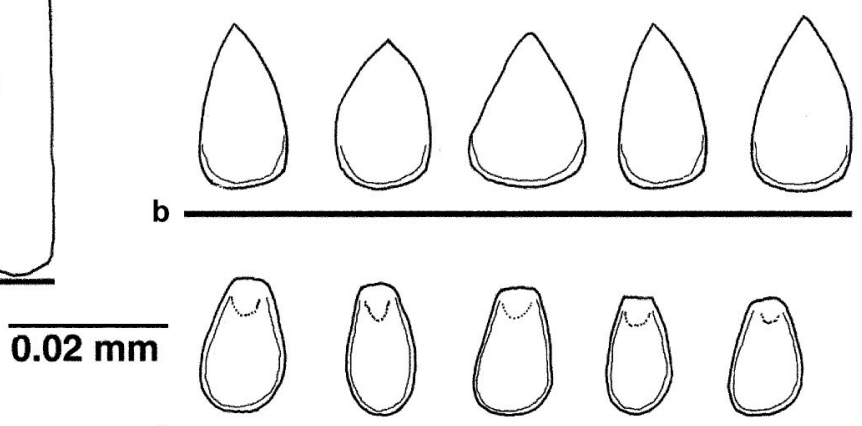

Figure 37-40. Dondersia namibiensis (LM). (37) Holotype, USNM no. 1184106; pedal pit everted. (38) In situ position of copulatory spicule and its anteroventral proximal scales as tissue was being dissolved in hypochlorite. (39) Left, ventral view of posterior (foot groove should be extending onto posteroventral lobe); right, ventral anterior end with shared opening of vestibule and mouth. (40) Sclerites ( $c f$. Fig. 35): a, scales from beside pedal groove; b, plectron-like scales with narrow rim; c subovate scales with narrow rim; $d$, rods, dotted lines (upper row) thickest part of sclerites near foot groove determined by birefringence. cs, copulatory spicule; mc, mantle cavity opening; mo, mouth; pp, pedal pit; pvl, posteroventral body lobe; ve, vestibule. 


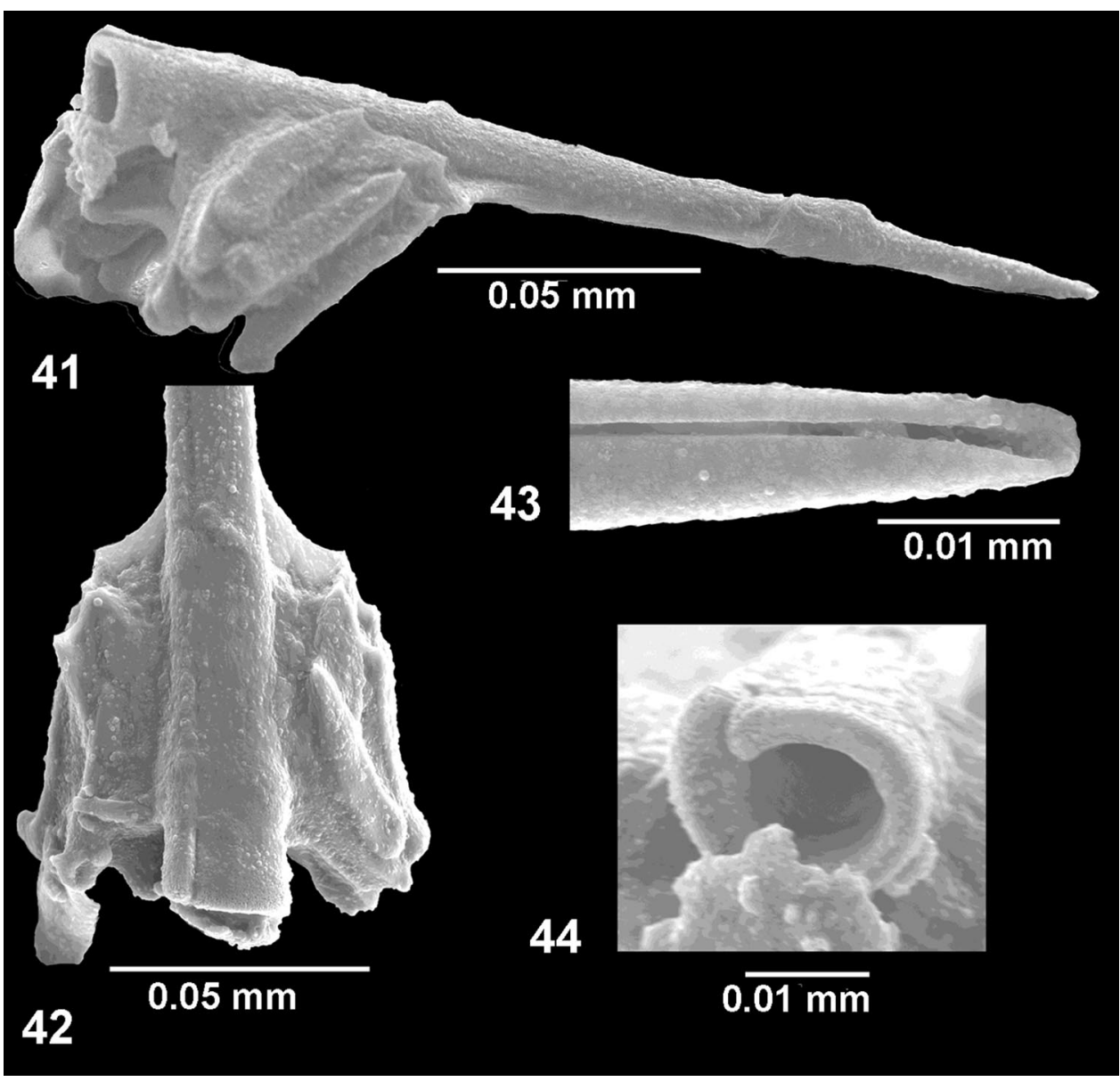

Figure 41-44. Copulatory spicule of Dondersia namibiensis (SEM), paratype USNM 1184110. (41) Entire, lateral view, with anteroventrally and proximally situated accessory scales ( $c f$. Fig. 38). (42) Paired groups of accessory scales, dorsal view. $(43,44)$ Distal and proximal ends, respectively, of copulatory spicule with two longitudinal edges curved toward each other, overlapping proximally, resulting in a tube. In 41 and 42 , membrane coats all but distal end. 

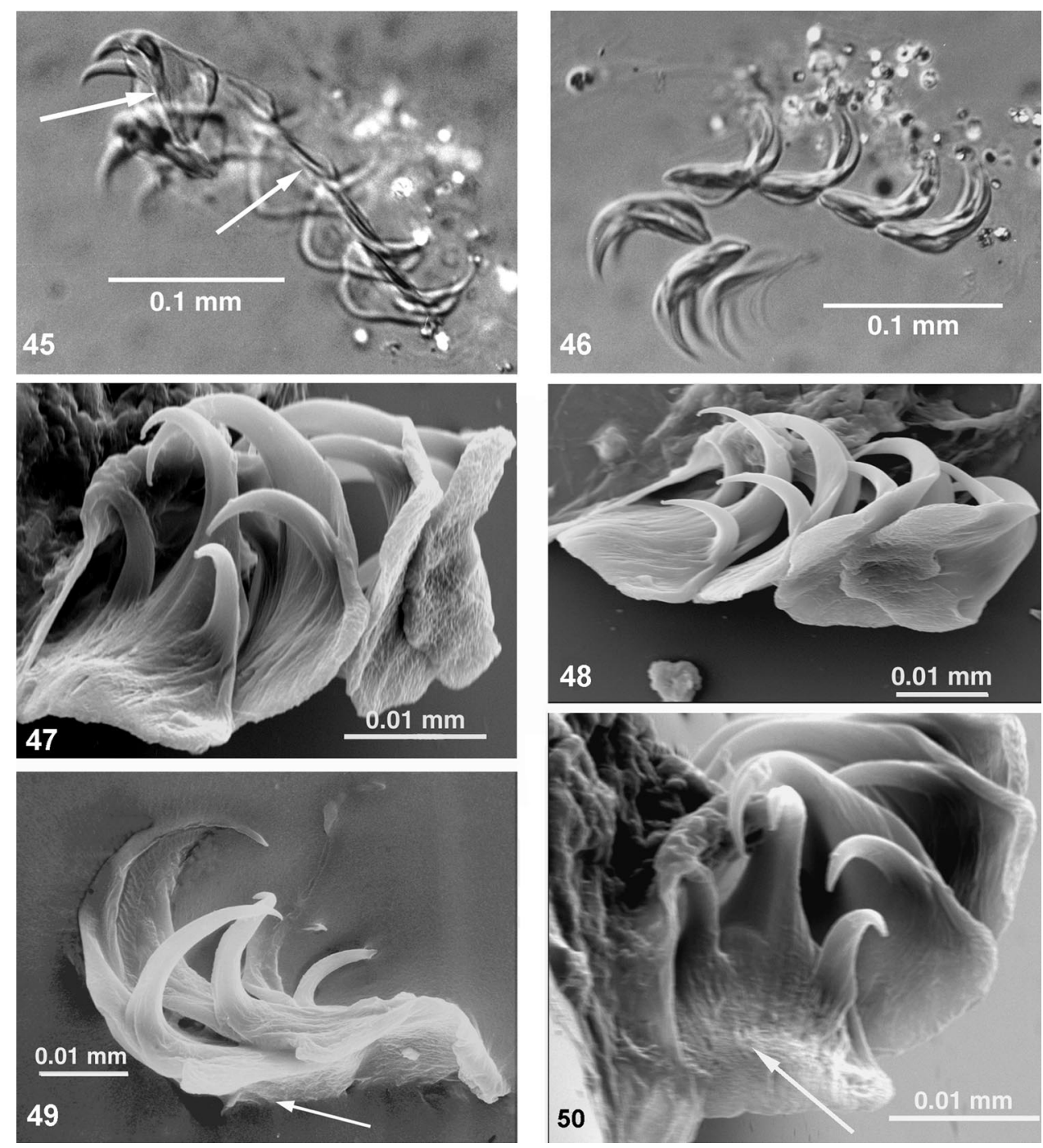

Figure 45-50. Radulae of Lyratoherpia carinata, L. namibiensis, and Dondersia incali. $(45,46)$ L. carinata paratype no. 2, USNM 1184104 (radula preparation lost); arrows indicate central ridges of lateral denticles continuing onto base (LM)(cf. Fig. 51). (47, 48, 50) D. namibiensis (SEM); arrow in Fig. 50, thin denticle-like serrations of tooth base and foremost lateral denticle positioned from medial to upward and outward. (49) $D$. incali (SEM); arrow, extremely thin radular membrane. 

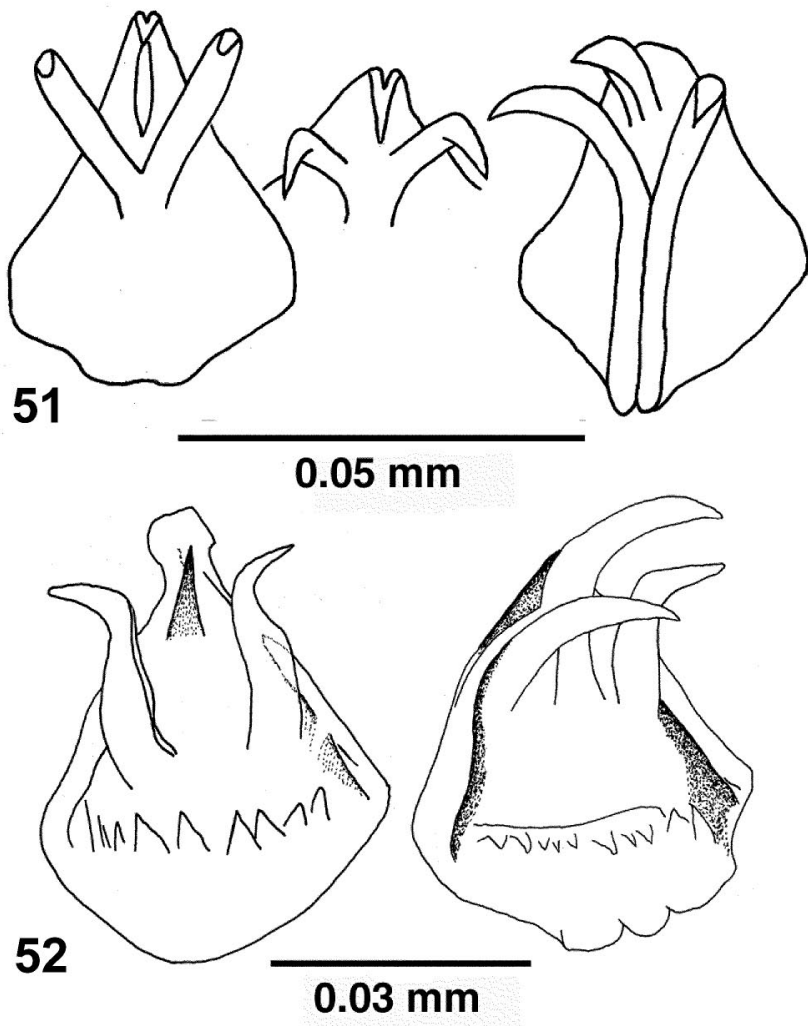

54
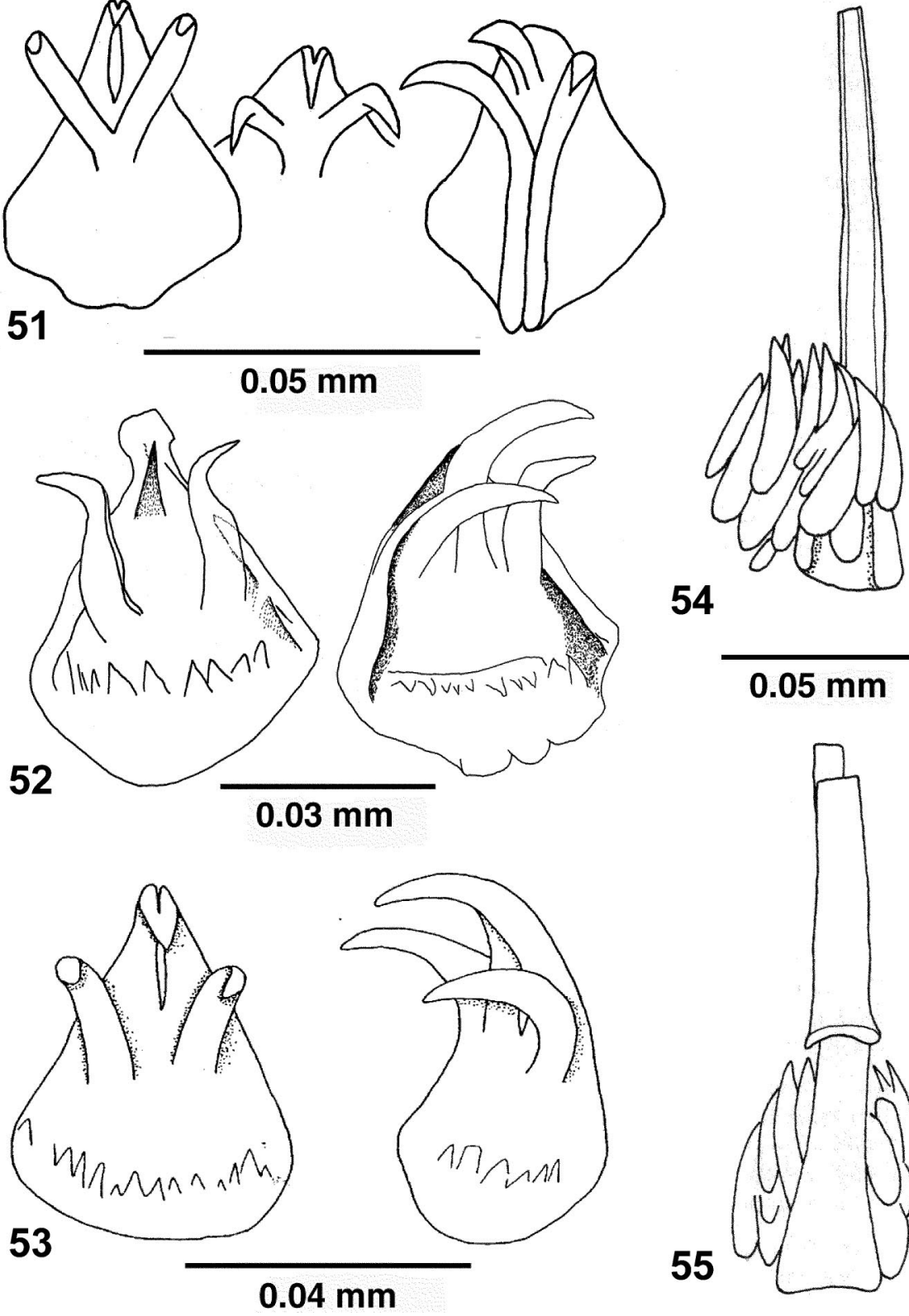

55
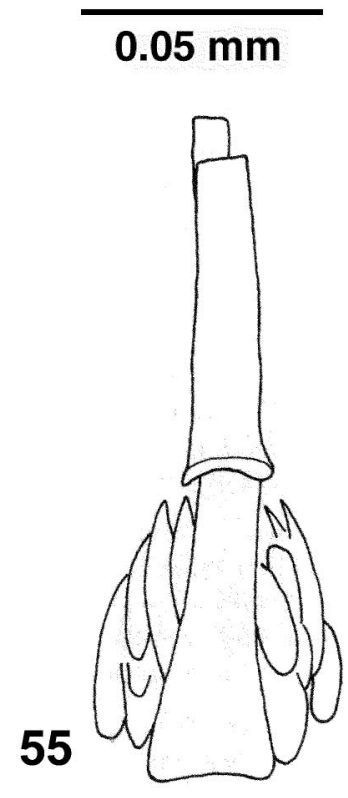

Figure 51-55. Single teeth of radulae in Lyratoherpia carinata and Dondersia namibiensis, and radula and copuatory spicule of $D$. incali. (51) L. carinata, same teeth as Figs. 45, 46, with central ridges of lateral denticles continuing across base to proximal end. (52) D. namibiensis, paratype USNM 1184110. (53) D. incali, paratype from type locality. Denticulations on base in D. namibiensis larger than those in $D$. incali but not larger than those in D. festiva (Fig. 6). $(54,55)$ Copulatory spicules of $D$. incali: 54 , laterally oblique, ventral to left, and 55 dorsal view (from Scheltema, 1999, fig. 5). 

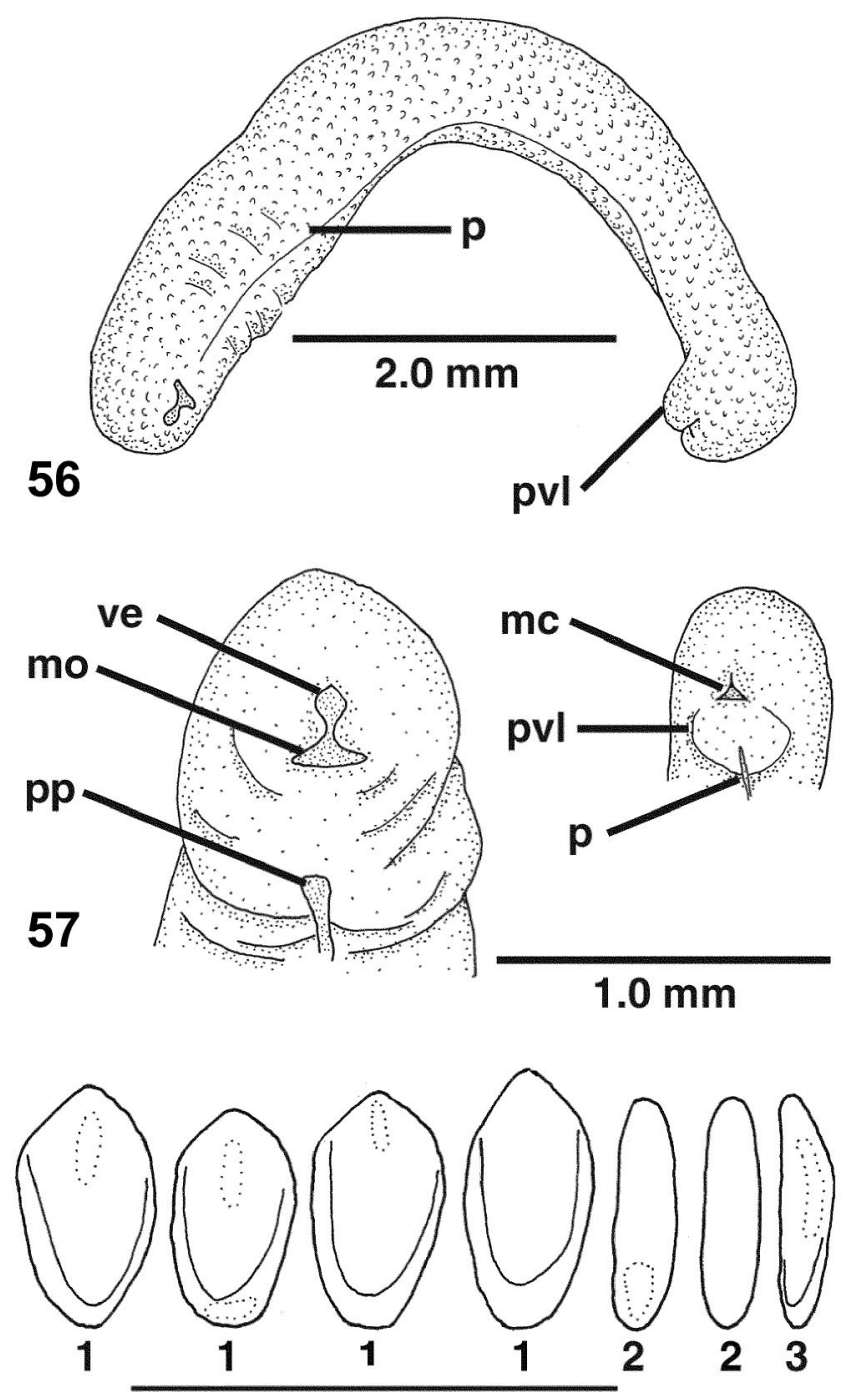

58

\section{$0.05 \mathrm{~mm}$}

Figure 56-58. Lyratoherpia carinata (LM). (56) Paratype no. 1, USNM 1184103 (cf. Fig. 61). (57) Anteroventral (left), mouth and vestibule sharing same opening, and posteroventral (right) with foot groove ending on posteroventral body lobe; same specimen as 56. (58) Sclerites, thickest areas determined by birefringence shown by dotted lines: 1 rimmed scales with thick rims and thickened medially and distally; 2 short, flattened rods; 3 foot-groove sclerite. See Fig. 59 sclerite no. 3 for fourth sclerite type. mc, mantle cavity opening; mo, mouth opening, shared; p, pedal groove, ending on posteroventral lobe; pp, pedal pit; pvl, posteroventral lobe; ve, vestibule opening, shared. 


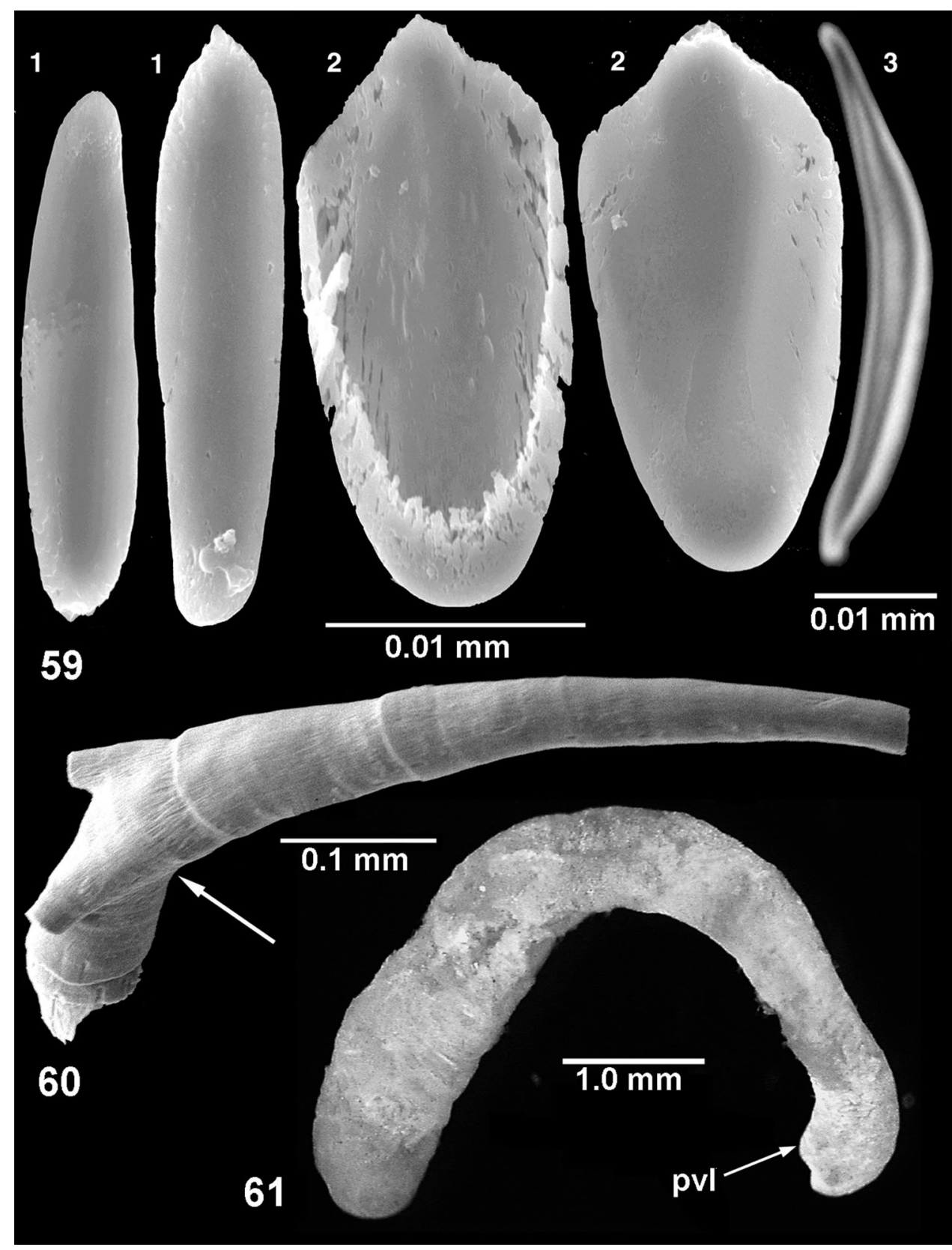

Figure 59-61. Lyratoherpia carinata. (59) Sclerites (SEM, except sclerite no. 3 LM, cross-polarized light): 1 , rods; 2 , rimmed scales ad- and abfrontal views; 3 , curved, rounded rod, probably from beside foot-groove sclerites (Fig. 58 no. 3); thicker than and twice as long as scales and common rods. (60) Copulatory spicule, SEM, one of a pair, proximal end on left; arrow, bend between short proximal end lying within copulatory spicule sac and long distal end lying within mantle cavity fold (cf. Figs. 68-70); paratype no. 2 USNM 1184104. (61) Paratype no. 1, USNM 1184103 (LM) with rounded anterior end to left and slight posteroventral lobe (pvl) to right. 

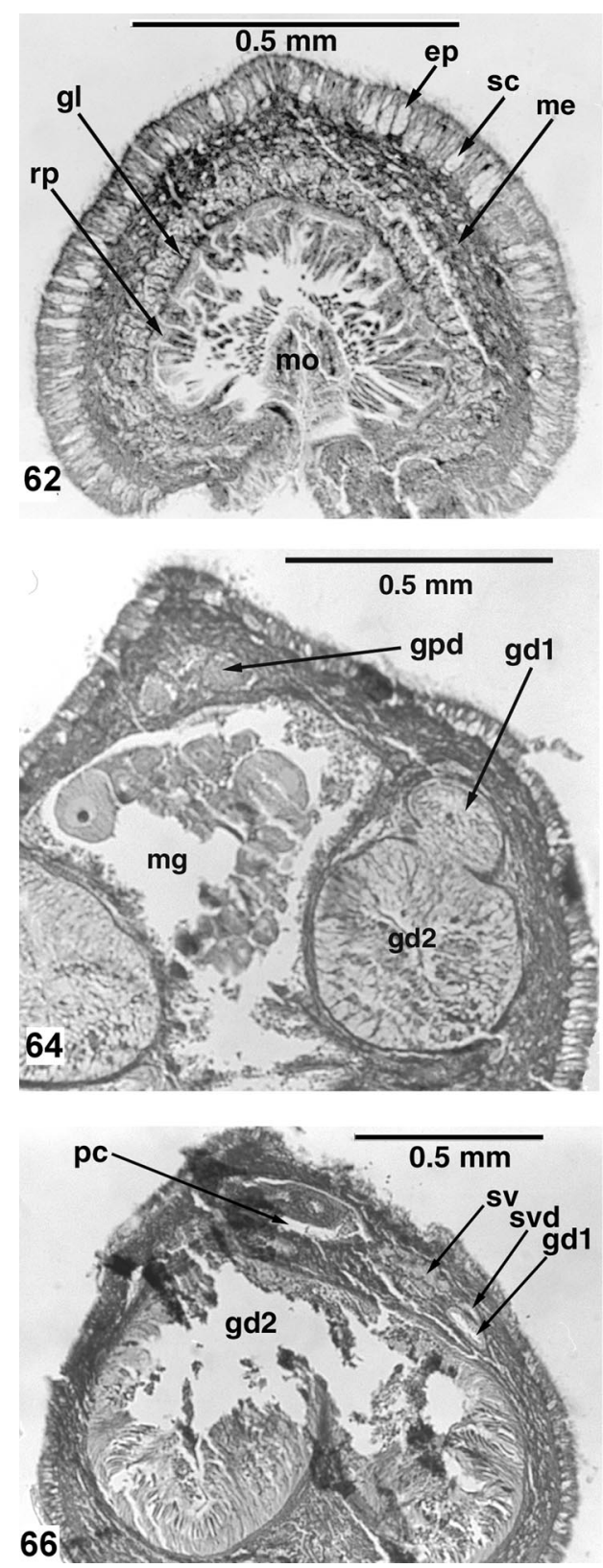
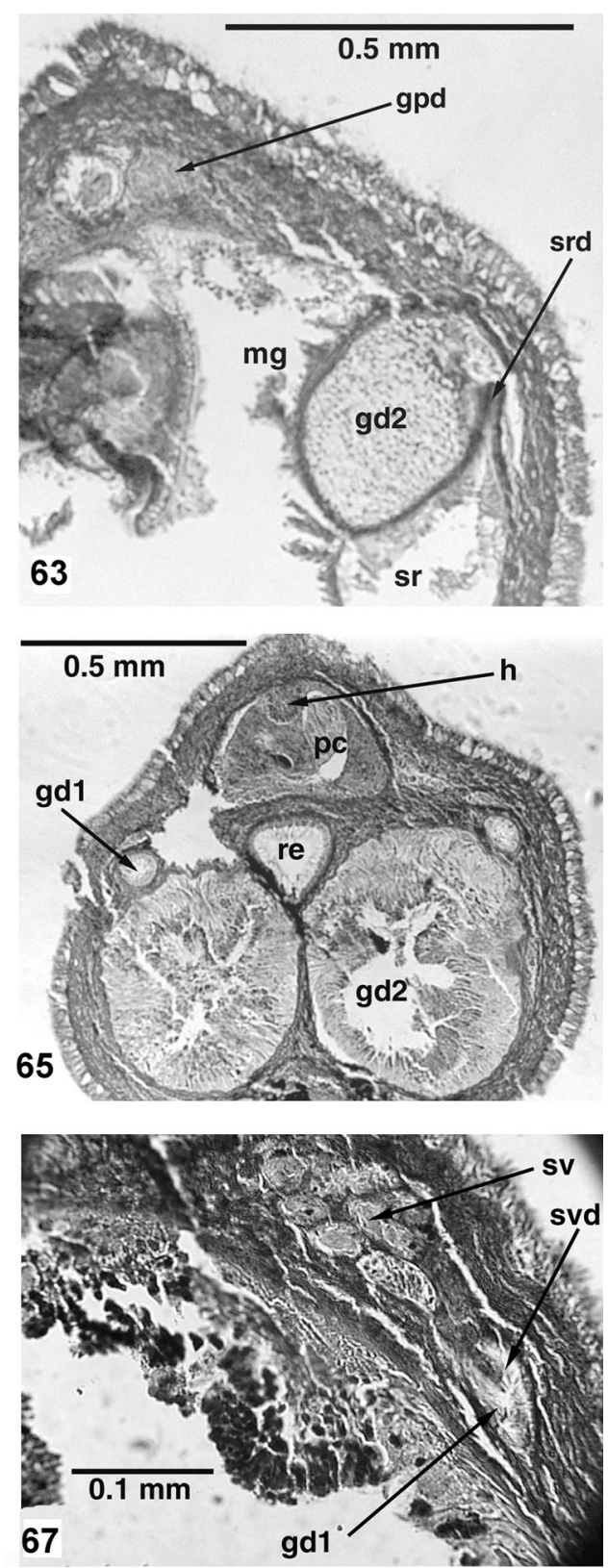

Figure 62-67. Lyratoherpia carinata histologic sections, paratype no. 3 USNM 1184105. Note dorsal carina. (62) Vestibule, mouth (mo) with shared opening, more than one papilla per root (rp), supravestibular glands (gl), numerous epidermal glands (ep), sclerite-forming cells (sc), and mesenchyme (me). (63-67) Reproductive system, anterior to posterior (cf. Fig. 24). (63) Opening of one of paired seminal receptacles through duct (srd) into the lower gametoduct (gd2). (64) Union of upper ( $g d 1)$ and lower (gd2) gametoducts; gonopericardial ducts (gpd) shortly before emptying into the pericardial cavity (presence of ova in midgut an artifact of contraction). (65) Narrow, paired upper gametoducts running dorsolaterally along paired lower gametoducts; pericardium (pc) with heart (h) and gametes. (66) Union of lower gametoducts; upper gametoducts with several lobes of seminal vesicles (sv) that empty through a common duct (svd) into the upper gametoduct shortly after it leaves the pericardial cavity. (67) Enlarged view of seminal vesicle lobes and their common duct to gametoduct 1 in section adjoining Fig. 66. Other letters: mg, midgut; re, rectum. 

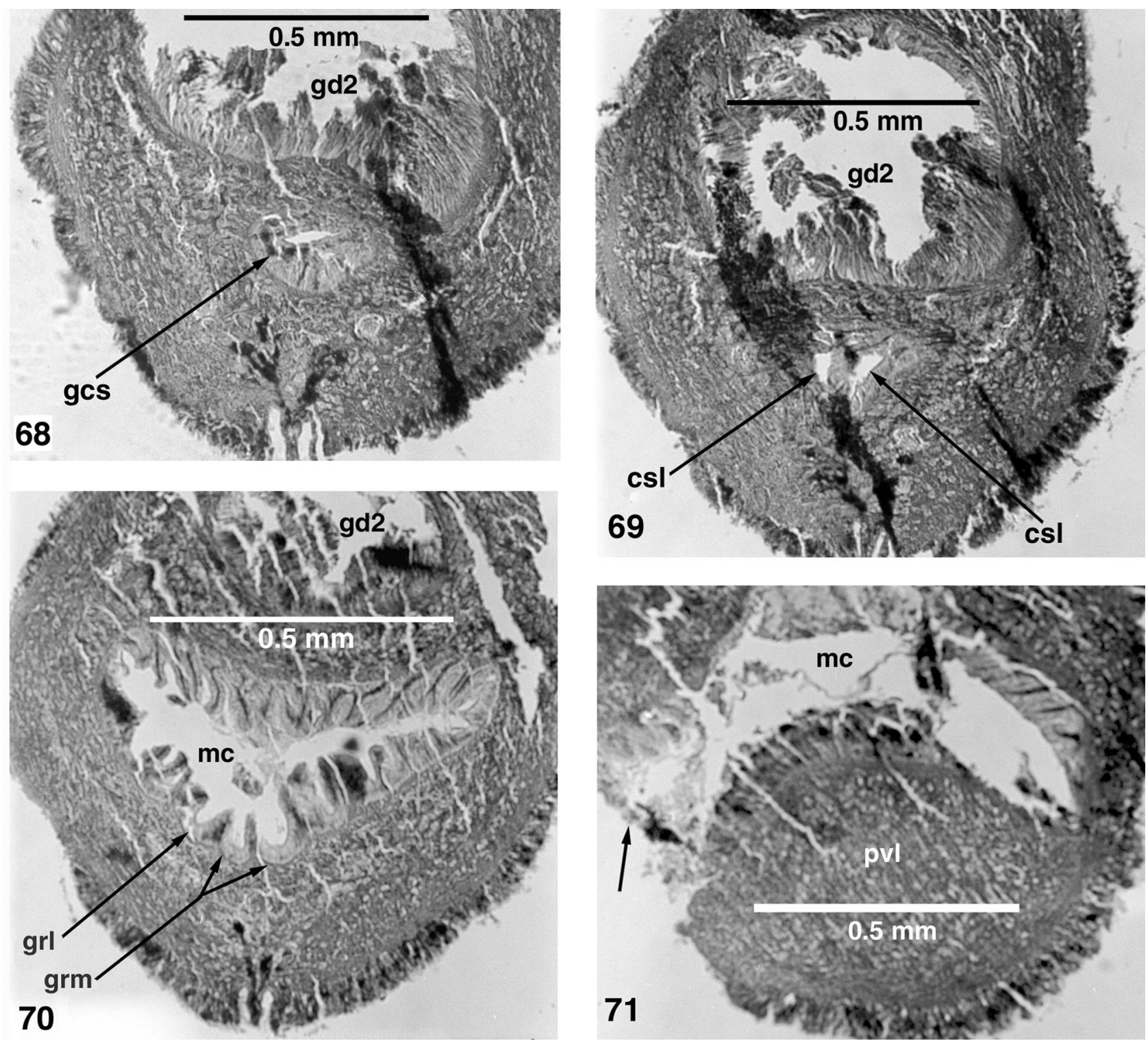

Figure 68-71. Reproductive system of Lyratoherpia carinata (cont'd, see Fig. 24). (68) Gland of copulatory spicule sac (gcs), lumen single. (69) Lumina of paired copulatory spicules (csl) within the copulatory spicule sac. (70) Ventral grooves in the mantle cavity (mc) wherein lie the long, paired copulatory spicules (grm) and their short side processes (grl); end of lower gametoduct emptying into mantle cavity shortly. (71) Posteroventral body lobe (pvl) solidly filled with mesenchyme with no connection to copulatory spicule sac and no lumen or opening into mantle cavity; arrow, mantle cavity opening to outside, section slightly posterior to opening of lower gametoduct $(\mathrm{gd} 2)$. 

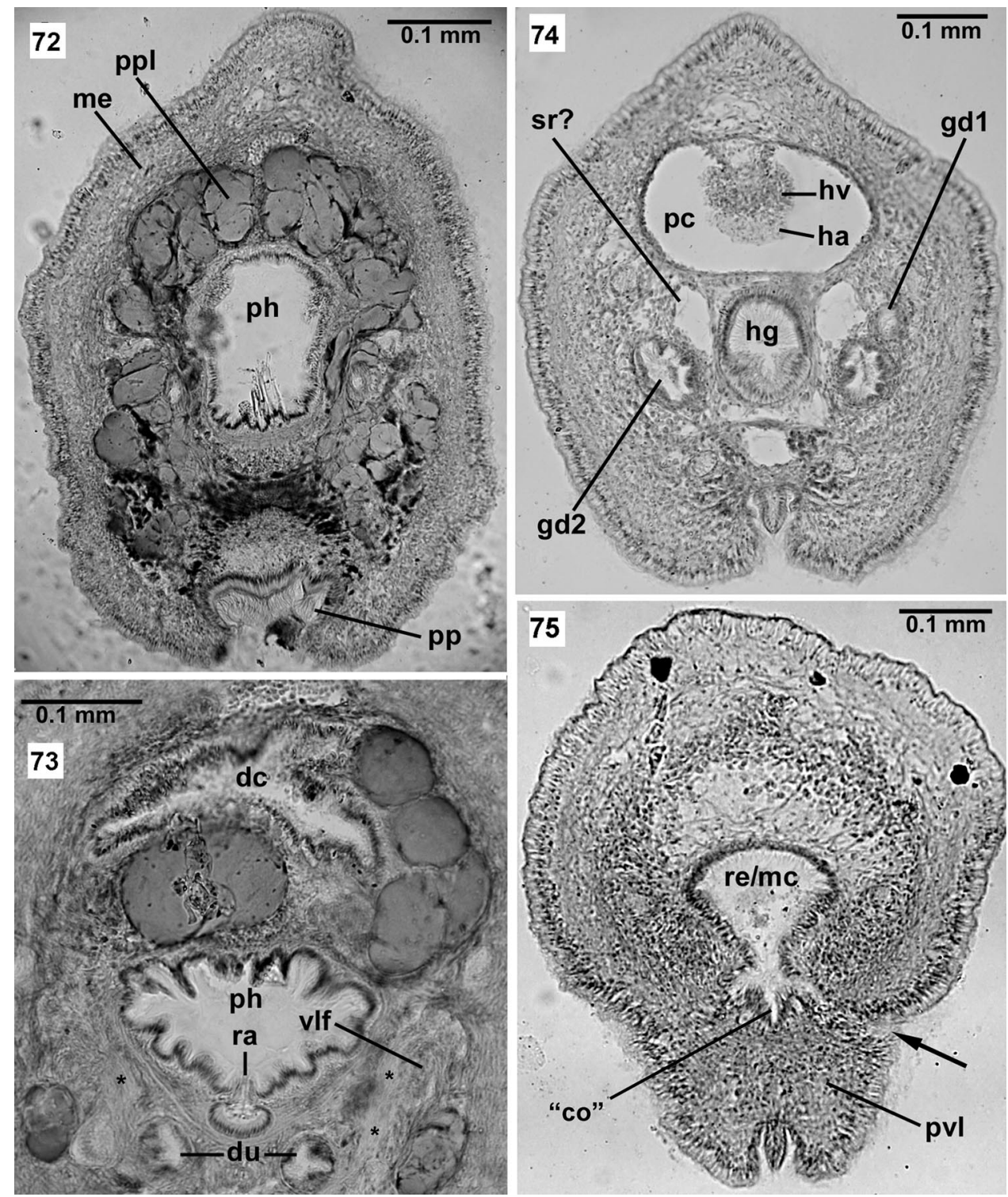

Figure 72-75. Lyratoherpia californica, thick holotype sections with yellowing balsam, juvenile; all sections with thick mesenchyme (me) filling hemocel. (72) Massive pedal pit glandular lobes (ppl) meeting mid-dorsally; body with dorsal carina; pedal pit (pp) narrow. (73) Ventrolateral foregut glands (vlf) with long, bundled, nonmuscular gland-cell necks (asterisks) leading from nonmuscular glandular cells to muscular ducts (du); monostichous radula (ra) opening into pharynx (ph) with many folds; single dorsal cecum (dc). (74) Reproductive system developing, of usual configuration, with possibly developing seminal receptacles (sr?) and scarcely developed gametoducts (upper gd1, lower gd2); hind gut (hg) with cells of rectum in lower half; ventricle (hv) and fused pair of auricles (ha) of heart in large pericardial cavity (pc). (75) Mesenchyme-filled posteroventral body lobe (pvl) with no lumen, "co" presumptive copulatory sac of ventral mantle cavity (Heath, 1918); end of rectum into small mantle cavity (re/mc); arrow, opening of mantle cavity around posteroventral lobe; narrow foot-fold extending onto posteroventral lobe. 


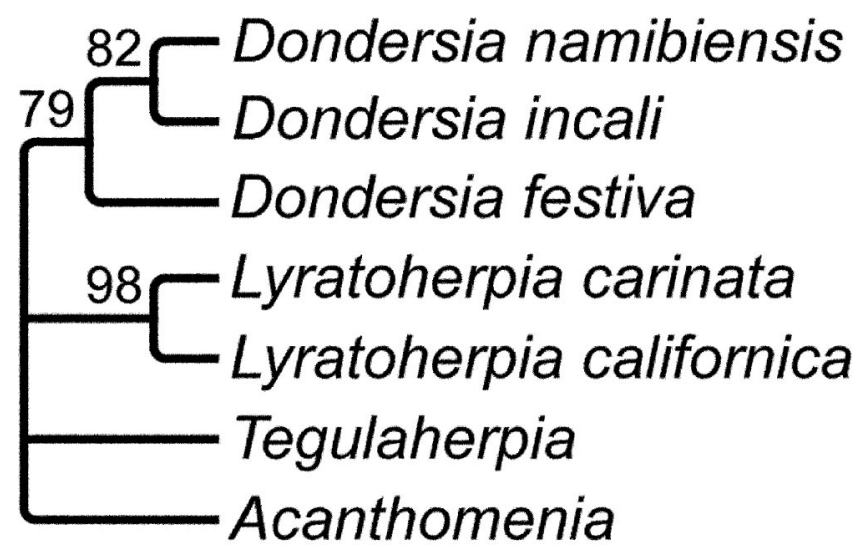

Figure 76. Majority rule consensus tree $(50 \%)$ of the three equally most parsimonious trees recovered in cladistic morphological analysis. Bootstrap support values are shown at each node. 